\title{
Start van de loopbaan na de Universiteit Maastricht 1997/1998
}

Citation for published version (APA):

Ramaekers, G. W. M. (2000). Start van de loopbaan na de Universiteit Maastricht 1997/1998.

Researchcentrum voor Onderwijs en Arbeidsmarkt, Faculteit der Economische Wetenschappen. ROA

Reports No. 1 https://doi.org/10.26481/umarep.2000001

Document status and date:

Published: 01/01/2000

DOI:

10.26481/umarep.2000001

Document Version:

Publisher's PDF, also known as Version of record

\section{Please check the document version of this publication:}

- A submitted manuscript is the version of the article upon submission and before peer-review. There can be important differences between the submitted version and the official published version of record.

People interested in the research are advised to contact the author for the final version of the publication, or visit the DOI to the publisher's website.

- The final author version and the galley proof are versions of the publication after peer review.

- The final published version features the final layout of the paper including the volume, issue and page numbers.

Link to publication

\footnotetext{
General rights rights.

- You may freely distribute the URL identifying the publication in the public portal. please follow below link for the End User Agreement:

www.umlib.nl/taverne-license

Take down policy

If you believe that this document breaches copyright please contact us at:

repository@maastrichtuniversity.nl

providing details and we will investigate your claim.
}

Copyright and moral rights for the publications made accessible in the public portal are retained by the authors and/or other copyright owners and it is a condition of accessing publications that users recognise and abide by the legal requirements associated with these

- Users may download and print one copy of any publication from the public portal for the purpose of private study or research.

- You may not further distribute the material or use it for any profit-making activity or commercial gain

If the publication is distributed under the terms of Article $25 \mathrm{fa}$ of the Dutch Copyright Act, indicated by the "Taverne" license above, 


\section{Start van de loopbaan na de Universiteit}

Maastricht 1997/1998

ROA-R-2000/1

G.W.M. Ramaekers

Researchcentrum voor Onderwijs en Arbeidsmarkt

Faculteit der Economische Wetenschappen en Bedrijfskunde Universiteit Maastricht

Maastricht, januari 2000 
ISBN 90-5321-269-8

SEC00.013/GR 


\section{Inhoud}

Bladzijde

Voorwoord

i

Samenvatting iii

1 Inleiding 1

1.1 Opzet Arbeidsmarktscanner UM 1

1.2 Leeswijzer 2

2 Resultaten $\mathrm{t}+1$ meting 1997 en 1998

2.1 Respons 5

2.2 Achtergrondkenmerken en kwalificaties $\quad 6$

$\begin{array}{lr}2.3 \text { Kans op werk } & 10\end{array}$

$\begin{array}{ll}2.4 \text { Kwaliteit van het werk } & 13\end{array}$

2.5 Loopbaanperspectieven 19

2.6 Oordeel over het werk $\quad 21$

2.7 Oordeel over de opleiding 25

3 Ontwikkeling arbeidsmarktintrede over de afgelopen vijf jaar 33

4 Arbeidsmarktintrede cohort 1997: vergelijking UM-landelijk 37

4.1 Vergelijking van de kans op werk en kwaliteit van het werk 37

4.2 Vergelijking van het oordeel over de opleiding 38

Bijlage: Technische toelichting $\quad 45$ 


\section{Voorwoord}

Het Researchcentrum voor Onderwijs en Arbeidsmarkt (ROA) verricht sinds 1990 periodiek onderzoek naar de arbeidsmarktintrede en loopbanen van afgestudeerden van de Universiteit Maastricht (UM). Dit gebeurt met behulp van de zogeheten 'Arbeidsmarktscanner UM'. De systematiek van deze scanner bestaat hieruit dat oud-studenten voor de eerste keer circa anderhalf jaar na het afstuderen worden bevraagd ( $t+1$ meting, waarmee de transitie van studie naar werk wordt gemeten). Zo'n vijf jaar na het afstuderen worden zij voor de tweede keer geënquêteerd ( $t+5$ meting) en tien jaar na het afstuderen voor de derde keer ( $t+10$ meting).

In dit rapport worden resultaten gepresenteerd van de eind 1997 gehouden $t+1$ meting onder afstudeerjaargang 1996 en de eind 1998 gehouden $t+1$ meting onder afstudeerjaargang 1997. Met betrekking tot de laatste meting worden de resultaten ten aanzien van de UM vergeleken met landelijke cijfers. Over de resultaten van de eind 1998/begin 1999 gehouden $t+5$ meting en $t+10$ meting wordt in een afzonderlijk ROA-rapport verslag gedaan.

De arbeidsmarktscanner wordt aan de UM toegepast in opdracht van het College van Bestuur. De toepassing vindt plaats in samenwerking met het Bureau Inschrijvingen van de Dienst Studentenzaken van de UM. Het Bureau Inschrijvingen zorgt voor het bijhouden van het adressenbestand van de alumni, het verzenden van de vragenlijsten en de non-responsactiviteiten. Het ROA is verantwoordelijk voor de methodologische en inhoudelijke aspecten van de arbeidsmarktscanner, stelt de jaarlijkse rapportages samen en beheert het bestand met onderzoeksgegevens. Het onderzoek wordt binnen het Bureau Inschrijvingen uitgevoerd door $\mathrm{H}$. Smit en S. Vogel en binnen het ROA door drs. G. Ramaekers (projectleider) en E. Soudant. Het project wordt intern begeleid door dr. R.K.W. van der Velden, hoofd van de afdeling Onderwijs en Beroepsloopbaan.

Maastricht, januari 2000 


\section{Samenvatting}

\section{Achtergrondkenmerken van UM afgestudeerden}

Bij alle faculteiten, behoudens de FdEWB, bestaat de meerderheid van de uitstroom uit vrouwen. De grootste groep afgestudeerden (bijna de helft) heeft hoog (op hboof universitair niveau) opgeleide ouders; bijna eenderde heeft ouders met een laag opleidingsniveau (lagere school, lagere beroepsopleiding, mavo of mulo).

Veel afgestudeerden betreden de arbeidsmarkt met kwalificaties die zij additioneel aan hun opleiding hebben opgedaan: bijna de helft heeft voor hun vakgebied relevante werkervaring (excl. stages) opgedaan en iets meer dan de helft beschikt over bestuurlijke ervaring. Bijna tweederde heeft tijdens de opleiding stage gelopen in Nederland.

Vier op de tien afgestudeerden heeft tijdens de opleiding aan de UM buitenlandervaring opgedaan: een op de vijf afgestudeerden heeft in het buitenland stage gelopen, eveneens een op de vijf heeft een studie-onderdeel in het buitenland gevolgd en een op de tien afgestudeerden heeft tijdens de opleiding anderszins buitenland-ervaring opgedaan.

\section{Arbeidsmarktintrede}

De economische hoogconjunctuur van de laatste jaren heeft er niet alleen toe bijgedragen dat het vinden van betaald werk voor pas afgestudeerden van de UM nauwelijks nog een probleem vormt, maar ook dat het gevonden werk de afgelopen vijf jaar steeds vaker aansluit bij hun opleidingsniveau en steeds beter wordt beloond. Tussen meetjaar 1997 en meetjaar 1998 is het aandeel van afgestudeerden die na het afstuderen nooit werkloos zijn geweest fors gestegen. Tegenover de toegenomen kans op werk staat evenwel dat het aandeel van afgestudeerden die werken als uitzend-, oproep- of invalkracht licht is toegenomen (ten koste van de in reguliere loondienst werkende afgestudeerden) evenals het aandeel van afgestudeerden in een tijdelijke aanstelling zónder uitzicht op een vaste aanstelling (ten koste van de tijdelijke aanstellingen mét uitzicht op een vaste aanstelling).

De meeste afgestudeerden hebben functies waarvoor een opleiding op universitair niveau is vereist. Dit laat onverlet dat eenderde werkt in een functie die volgens de werkgever ook door een opgeleide op HBO-niveau mag worden vervuld. Ruim driekwart heeft werk dat aansluit bij de gevolgde opleidingsrichting, dat wil zeggen functies waarvoor de eigen of een daaraan verwante opleidingsrichting door de werkgever werd vereist. 


\section{Oordeel over het werk}

Negen van de tien afgestudeerden vinden dat hun functie voldoende mogelijkheden biedt om zichzelf verder te ontwikkelen (hoewel 'slechts' eenderde verwacht al binnen één jaar promotie te maken naar een hogere functie). Verder blijkt dat de meerderheid van de afgestudeerden de aansluiting van het gevonden werk op de gevolgde opleiding als goed of voldoende kwalificeert en in het algemeen tevreden is over het gevonden werk. Bij de meesten voldoet het gevonden werk ook aan de verwachtingen omtrent werk die zij al tijdens hun opleiding hadden. Overigens varieert de algemene tevredenheid over het gevonden werk met de gevolgde opleidingsrichting (afgestudeerden van de FdGW en FdR zijn minder tevreden met hun werk dan afgestudeerden van de FdEWB), met de aansluiting opleiding-werk naar niveau en richting (afgestudeerden met werk dat aansluit bij het niveau en de richting van hun opleiding zijn meer tevreden over hun werk dan afgestudeerden met werk dat niet aansluit bij hun opleiding) en met de zekerheid van het werk (afgestudeerden met een vaste aanstelling zijn meer tevreden dan afgestudeerden met een tijdelijke aanstelling).

Tenminste $80 \%$ van alle afgestudeerden vindt afwisseling, zelfstandigheid, uitdaging, omgaan met collega's, verantwoordelijkheid, verdere ontwikkeling van expertise en creativiteit belangrijke aspecten van werken. De aspecten erkenning door anderen, werkzekerheid, combineren van werk met privéleven, maatschappelijke relevantie van het werk alsmede hoog inkomen scoren iets minder hoog in belangrijkheid, hoewel deze aspecten toch nog altijd door meer dan de helft van alle afgestudeerden belangrijk worden gevonden. Overigens vindt bij elk van deze aspecten, behoudens een hoog inkomen, meer dan de helft van de betaald-werkende afgestudeerden dat zij het desbetreffende aspect in sterke mate in hun huidige werksituatie kunnen realiseren. Minder dan de helft schat in dat zij een hoog inkomen in hun huidige werksituatie kunnen realiseren.

\section{Oordeel over de opleiding}

De opleidingsaspecten waarover afgestudeerden het best zijn te spreken betreffen de coherentie van het vakkenpakket, de keuzemogelijkheden in de studie, de kwaliteit van het docentencorps en de opleiding als geheel. Deze aspecten worden met een gemiddeld rapportcijfer van 7 het beste beoordeeld, gevolgd door de studiebegeleiding en de voorbereiding op de beroepspraktijk, die in de ogen van de afgestudeerden voldoende scoren. Het enige opleidingsaspect dat naar de mening van de afgestudeerden net niet voldoende scoort, is de voorlichting over de arbeidsmarkt.

De algehele tevredenheid over de gevolgde opleiding hangt naast de gevolgde opleidingsrichting (basisartsen zijn het meest tevreden) op de eerste plaats samen met de tevredenheid over de kwaliteit van de docenten, op de tweede plaats gevolgd door de tevredenheid over de samenhang tussen de vakken, de keuzemogelijkheden in de studie, de voorbereiding op de beroepspraktijk, de mate van specia- 
lisatie van de opleiding en op de derde plaats gevolgd door de tevredenheid over de arbeidsmarktvoorlichting.

Ruim driekwart van de afgestudeerden is achteraf tevreden met de destijds gemaakte studiekeuze: als zij opnieuw mochten kiezen zouden zij weer dezelfde opleiding aan de UM zijn gaan volgen.

Vergelijking UM-landelijk

Uit de vergelijking van afgestudeerden van de UM met elders afgestudeerden is naar voren gekomen dat afgestudeerden van de UM niet significant afwijken van afgestudeerden van andere universiteiten wat betreft de kans op werk (werkloosheid), zekerheid van het werk (aandeel vaste aanstellingen) en de aansluiting van het werk naar opleidingsniveau en -richting. Er zijn wel significante, faculteitspecifieke verschillen tussen afgestudeerden van de UM en elders afgestudeerden als het gaat om het oordeel over sommige aspecten van de opleiding. 


\section{Inleiding}

\subsection{Opzet Arbeidsmarktscanner UM}

Het project Arbeidsmarktscanner UM behelst een langlopend onderzoek naar de arbeidsmarktintrede en loopbaanontwikkeling van oud-studenten van de Universiteit Maastricht (UM). Het onderzoek gebeurt in opdracht van het College van Bestuur van de UM en wordt verricht door het Researchcentrum voor Onderwijs en Arbeidsmarkt $(R O A)$ in samenwerking met de Dienst Studentenzaken. Het onderzoek bestaat jaarlijks uit drie schriftelijke metingen: respectievelijk 1,5 jaar na afstuderen $(t+1)$, en vanaf 1998 tevens 5 jaar na afstuderen $(t+5)$ en 10 jaar na afstuderen $(t+10)$.

\section{t+1 meting}

De $t+1$ meting is gericht op het in kaart brengen van de arbeidsmarktintrede van afgestudeerden. Deze meting wordt jaarlijks gehouden in de maanden oktober januari onder alle afgestudeerden van het daaraan voorafgaande studiejaar. Dit komt neer op één tot anderhalf jaar na het afstuderen, afhankelijk van de maand waarin men is afgestudeerd en de maand waarin men de vragenlijst heeft ingevuld. De $t+1$ meting geeft aldus informatie over de transitie van de UM naar de arbeidsmarkt. De gehanteerde vragenlijst bevat vragen over de persoon, de afgesloten opleiding, de vooropleiding, de eventuele werk- en bestuurservaring vóór het afstuderen, de belangrijkste activiteiten na het afstuderen tot het moment van enquêteren, de huidige arbeidsmarktpositie, eventueel gevolgd onderwijs na het afstuderen en, bij betaald-werkenden, enkele kenmerken van de huidige functie en van de organisatie waarin men werkzaam is alsmede vragen over de aansluiting van de genoten opleiding op de beroepspraktijk.

De meest recente $t+1$ meting, die eind 1998 heeft plaatsgevonden, betrof degenen die in de periode oktober 1996 - september 1997 aan de UM zijn afgestudeerd (cohort 1997) ${ }^{1}$. Het gaat om in totaal 1.119 afgestudeerden. Hiervan hebben er 616 aan het onderzoek meegewerkt, hetgeen neerkomt op een respons van $55 \%$. Aan deze meting hebben voor de eerste keer ook afgestudeerden van alle Nederlandse universiteiten deelgenomen. Dit maakt het mogelijk om de resultaten met betrekking tot de Faculteit der Economische Wetenschappen en Bedrijfskunde (FdEWB), Faculteit der Geneeskunde ( $F d G)$ en Faculteit der Rechtsgeleerdheid (FdR) af te zetten tegen de desbetreffende landelijke cijfers. Vanwege het unieke karakter van de opleidingen cultuurwetenschappen en gezondheidswetenschappen is een vergelijking van de resultaten met betrekking tot de Faculteit der Cultuurweten-

1. Aan deze meting hebben de eerste afgestudeerden kennistechnologie meegedaan. Aangezien het vooralsnog slechts 2 respondenten betreft, wordt hierover niet afzonderlijk gerapporteerd. 
schappen (FdCW) en Faculteit der Gezondheidswetenschappen (FdGW) met landelijke resultaten weinig zinvol.

Over de resultaten van deze $t+1$ meting wordt op verschillende wijzen gerapporteerd. In de eerste plaats ten behoeve van het College van Bestuur van de UM in de vorm van een Management Summary. Deze bevat een beknopte weergave van recente ontwikkelingen in de arbeidsmarktintrede van afgestudeerden van de UM (zowel voor de UM als totaal als per afzonderlijke faculteit), alsmede een vergelijking met landelijke cijfers (voor respectievelijk de FdEWB, FdG en FdR). Daarnaast wordt over de resultaten van deze $t+1$ meting aan de afzonderlijke faculteiten gerapporteerd in de vorm van faculteitsrapporten. Vanwege de verschillende informatiebehoeften bij de diverse geledingen van de faculteiten zijn deze faculteitsrapporten onderverdeeld in drie, afzonderlijk te gebruiken, delen. Namelijk: een managementdeel met samenvattende kerncijfers per faculteit/opleiding, een statistisch overzicht met gedetailleerde tabellen per opleiding/afstudeerrichting en informatie over individuele afgestudeerden die daarvoor toestemming hebben verleend. Waar mogelijk worden de resultaten over de eigen faculteit afgezet tegen de desbetreffende landelijke resultaten.

$t+5$ en $t+10$ meting

De $t+5$ meting en $t+10$ meting zijn gericht op het in kaart brengen van het verdere verloop van de beroepsloopbaan van afgestudeerden. De in de $t+5$ meting en $t+10$ meting gebruikte vragenlijsten zijn ontwikkeld door aan te haken bij een onderzoeksproject onder afgestudeerden van het hoger onderwijs in een negental Europese landen en Japan, waarbij het ROA vanuit Nederland is betrokken. Dit is gebeurd in het kader van het EU-programma Targeted Socio-Economic Research (TSER). Deze TSER-meting heeft in het najaar van 1998 plaatsgevonden en had voor Nederland betrekking op een landelijke steekproef uit de bestanden van de Informatiebeheergroep (IBG) van 7.000 afgestudeerden van studiejaar 1994/1995 (4.390 afgestudeerden $\mathrm{HBO}$ en 2.610 afgestudeerden WO) en 6.000 afgestudeerden van studiejaar 1990/1991 (4.000 afgestudeerden HBO en 2.000 afgestudeerden WO). De TSER-meting heeft derhalve 3 respectievelijk 7 jaar na het afstuderen plaatsgevonden.

Het onderhavige rapport doet verslag van de resultaten van de twee laatst gehouden $t+1$ metingen. Over de resultaten van de $t+5$ meting en $t+10$ meting wordt in een separaat ROA-rapport verslag gedaan.

\subsection{Leeswijzer}

In hoofdstuk 2 worden resultaten gepresenteerd van de eind 1997 gehouden $\mathrm{t}+1$ meting onder afstudeerjaargang 1996 en de eind 1998 gehouden $t+1$ meting onder afstudeerjaargang 1997. Het hoofdstuk start in paragraaf 2.1 met een beschrijving van de respons, gevolgd in paragraaf 2.2 door een schets van enkele achtergrondkenmerken en kwalificaties waarmee deze afstudeerjaargangen de arbeidsmarkt 
betreden. In aansluiting hierop wordt de transitie van de universiteit naar de arbeidsmarkt in kaart gebracht aan de hand van achtereenvolgens de kans op werk in paragraaf 2.3 en de kwaliteit van het werk in paragraaf 2.4 . In de vragenlijsten wordt ieder jaar additioneel een beperkt aantal vragen opgenomen die betrekking hebben op een bepaald thema. In meting 1997 had het thema betrekking op loopbaanperspectieven. Paragraaf 2.5 doet verslag van de resultaten met betrekking tot dit thema. Paragraaf 2.6 beschrijft de resultaten van het thema van meting 1998, dat betrekking had op het oordeel van de afgestudeerden over hun huidige werk. Hoofdstuk 2 wordt in paragraaf 2.7 afgesloten met een bespreking van het oordeel van de afgestudeerden over de genoten opleiding.

Hoofdstuk 3 bevat een schets van de ontwikkelingen met betrekking tot de arbeidsmarktintrede van afgestudeerden van de UM over de afgelopen vijf jaar. Deze ontwikkelingen worden geschetst aan de hand van de ontwikkeling van achtereenvolgens de kans op werk, de zekerheid van het werk, de beloning en de aansluiting tussen de gevolgde opleiding en het uitgeoefende werk naar respectievelijk niveau en richting.

In hoofdstuk 4 worden voor afstudeerjaargang 1997 de resultaten met betrekking tot de UM afgezet tegen de desbetreffende landelijke cijfers. De vergelijking betreft achtereenvolgens de kans op werk en kwaliteit van het werk (paragraaf 4.1) en het oordeel over de gevolgde opleiding (paragraaf 4.2).

Een technische toelichting op de gepresenteerde cijfers is opgenomen in de bijlage. 


\section{Resultaten $\mathrm{t}+1$ meting 1997 en 1998}

\subsection{Respons}

Tot de t+1 meting 1996 heeft de onderzoekspopulatie van de UM bestaan uit degenen die een doctoraalgetuigschrift hebben behaald aan de FdEWB, FdGW of $F d R$, alsmede degenen die aan de FdG voor het basisartsexamen zijn geslaagd. Vanaf de t+1 meting 1996 is het onderzoek uitgebreid met afgestudeerden van de FdCW en vanaf $t+1$ meting 1998 met afgestudeerden van de Faculteit der Algemene Wetenschappen (FdAW).

Tabel 2.1

Respons $t+1$ meting 1997 en 1998 naar faculteit

\begin{tabular}{lccc}
\hline & N afgestudeerden & $n$ respondenten & respons \\
\hline FdAW & & & \\
1998 & 4 & & $50 \%$ \\
FdCW & & 19 & \\
1997 & 30 & 20 & $63 \%$ \\
1998 & 36 & & \\
FdEWB & & 269 & $65 \%$ \\
1997 & 415 & 157 & $51 \%$ \\
1998 & 309 & & $69 \%$ \\
FdG & & 94 & \\
1997 & 136 & 97 & $61 \%$ \\
1998 & 140 & 259 & $59 \%$ \\
FdGW & & & \\
1997 & & & $49 \%$ \\
1998 & 428 & 161 & $47 \%$ \\
FdR & 369 & 122 & $60 \%$ \\
1997 & & & $55 \%$ \\
1998 & 330 & 802 & \\
UM totaal & 261 & 616 & \\
1997 & & & \\
1998 & 1.339 & & \\
\hline
\end{tabular}

In de eind 1997 - begin 1998 gehouden t+1 meting (meting 1997) is nagegaan hoe de transitie van de UM naar de arbeidsmarkt is verlopen bij degenen die in de periode oktober 1995 - september 1996 aan de UM zijn afgestudeerd (cohort 1996). In de eind 1998 - begin 1999 gehouden $t+1$ meting (meting 1998) is nagegaan hoe de transitie van de UM naar de arbeidsmarkt is verlopen bij degenen die in de periode oktober 1996 - september 1997 aan de UM zijn afgestudeerd (cohort 1997). Tabel 2.1 geeft een overzicht van de respons op deze metingen, uitgesplitst naar faculteit. De tabel laat zien dat de respons tussen beide metingen is teruggelopen met $5 \%$-punt. De teruggang in respons is het grootst geweest bij afgestudeerden van de FdEWB. De daling van de respons speelt overigens niet alleen bij de UM 
maar over de hele linie van het schoolverlatersonderzoek. Hierbij kunnen verschillende factoren een rol spelen. Zo is met het groter worden van onderwijsinstellingen de binding van de afgestudeerden met de instellingen minder groot geworden. Daarbij komt dat studenten steeds meer onder druk staan om de studie binnen de daarvoor gestelde termijn af te ronden. Het gevolg hiervan is dat velen geen tijd meer vinden om deel te nemen aan activiteiten vanuit studentenverenigingen en/of de instellingen. Een gevolg hiervan is wederom dat de binding met de instelling terugloopt. Ook de toenemende individualisering van de samenleving komt de bereidheid om aan enquête-onderzoek mee te werken niet ten goede. Verder bestaat de indruk dat er steeds meer enquêtes worden uitgestuurd aan schoolverlaters en afgestudeerden. Hoe het ook zij, aan de laatste $t+1$ meting heeft toch nog altijd ruim de helft van de afgestudeerden meegewerkt, hetgeen relatief hoog is voor een uitgebreide schriftelijke meting. Thans varieert de respons van $47 \%$ onder afgestudeerde juristen tot $69 \%$ onder basisartsen.

Omdat de eerste lichting afgestudeerden van de FdAW in het onderzoeksbestand uit nog slechts 2 personen bestaat, worden de resultaten met betrekking tot deze faculteit in dit rapport niet weergegeven. Wel zijn de onderzoeksgegevens van deze afgestudeerden van de FdAW steeds verdisconteerd in de berekeningen van de totaalcijfers van de UM. Vanwege het klein aantal afgestudeerden van de FdCW in het onderzoekbestand, dienen de resultaten met betrekking tot deze faculteit met de nodige voorzichtigheid te worden geïnterpreteerd.

Bijna een kwart (24\%; vorige meting 18\%) van de afgestudeerden van de FdGW en $7 \%$ (vorige meting 6\%) van de afgestudeerden van de FdR in het onderzoeksbestand heeft de opleiding in deeltijd gevolgd. Aangezien deeltijdstudenten na het afstuderen veelal blijven werken in de baan die zij al tijdens hun opleiding hadden, is hun arbeidsmarktintrede niet goed vergelijkbaar met die van afgestudeerden van voltijdopleidingen. Om deze reden worden in de tabellen van dit hoofdstuk eerst de gegevens voor achtereenvolgens de UM als geheel (UM totaal), het totaal van de deeltijdopleidingen (UM deeltijd) en het totaal van de voltijdopleidingen (UM voltijd) gepresenteerd, gevolgd door een faculteitsgewijze vergelijking van de voltijdopleidingen.

\subsection{Achtergrondkenmerken en kwalificaties}

In tabel 2.2 wordt de uitstroom van de UM getypeerd aan de hand van twee achtergrondkenmerken, namelijk geslacht en sociale herkomst.

\section{Geslacht}

Zowel in studiejaar 1995/96 (meting 1997) als in studiejaar 1996/97 (meting 1998) bestaat de meerderheid van de uitstroom van de UM uit vrouwen. In meting 1997 waren vrouwen iets sterker (hoewel niet significant) vertegenwoordigd onder afgestudeerden van voltijdopleidingen dan onder afgestudeerden van deeltijdopleidingen. In meting 1998 zijn vrouwen significant sterker vertegenwoordigd onder 
afgestudeerden van deeltijdopleidingen dan onder afgestudeerden van voltijdopleidingen.

Hoewel het aandeel van vrouwen in de uitstroom van de FdCW en FdR ten opzichte van de vorige meting is gedaald, kan bij alle faculteiten worden geconstateerd dat de meerderheid van de uitstroom nog steeds uit vrouwen bestaat, de FdEWB uitgezonderd.

\section{Sociale herkomst}

Eenmalig, namelijk in meting 1998, is gevraagd naar het hoogst behaalde opleidingsniveau van zowel de vader als de moeder van de afgestudeerde. Als indicator voor de sociale herkomst van de afgestudeerden is gebruik gemaakt van het hoogst behaalde opleidingsniveau van hetzij de vader (indien de vader een hoger opleidingsniveau heeft dan de moeder), hetzij de moeder (indien de moeder een hoger opleidingsniveau heeft dan de vader), hetzij beiden (indien beiden hetzelfde opleidingsniveau hebben).

Tabel 2.2

Typering uitstroom naar geslacht (meting 1997 en 1998) en sociale herkomst (meting 1998)

\begin{tabular}{|c|c|c|c|c|c|}
\hline & \multicolumn{2}{|c|}{$\begin{array}{l}\text { Geslacht } \\
\% \text { vrouw }\end{array}$} & \multicolumn{3}{|c|}{ laag $\begin{array}{c}\text { sociale herkomst } \\
\text { midden hoog }\end{array}$} \\
\hline $\begin{array}{l}\text { UM totaal } \\
\text { UM deeltijd } \\
\text { UM voltijd }\end{array}$ & $\begin{array}{l}62 \% \\
52 \% \\
63 \%\end{array}$ & $\begin{array}{l}61 \% \\
76 \% \\
60 \%\end{array}$ & $\begin{array}{l}32 \% \\
57 \% \\
29 \%\end{array}$ & $\begin{array}{l}20 \% \\
14 \% \\
21 \%\end{array}$ & $\begin{array}{l}48 \% \\
29 \% \\
50 \%\end{array}$ \\
\hline $\begin{array}{l}\text { FdCW } \\
\text { FdEWB } \\
\text { FdG } \\
\text { FdGW } \\
\text { FdR }\end{array}$ & $\begin{array}{l}89 \% \\
41 \% \\
63 \% \\
84 \% \\
70 \%\end{array}$ & $\begin{array}{l}75 \% \\
37 \% \\
62 \% \\
81 \% \\
57 \%\end{array}$ & $\begin{array}{l}25 \% \\
25 \% \\
33 \% \\
32 \% \\
29 \%\end{array}$ & $\begin{array}{l}15 \% \\
21 \% \\
19 \% \\
21 \% \\
22 \%\end{array}$ & $\begin{array}{l}60 \% \\
54 \% \\
48 \% \\
47 \% \\
49 \%\end{array}$ \\
\hline
\end{tabular}

Tabel 2.2 laat zien dat bijna eenderde (32\%) van de afgestudeerden ouders heeft met een laag opleidingsniveau (lagere school, lagere beroepsopleiding, mavo of mulo). Een op de vijf (20\%) afgestudeerden heeft ouders met een middelbaar opleidingsniveau (havo, mms, vwo, hbs, gymnasium of mbo). Bijna de helft (48\%) van de afgestudeerden heeft hoog (hbo of universiteit) opgeleide ouders. Afgestudeerden van de deeltijdopleidingen hebben vaker laag opgeleide ouders dan afgestudeerden van voltijdopleidingen. Vergeleken met afgestudeerden van andere faculteiten hebben afgestudeerden van de $\mathrm{FdCW}$ het vaakst hoog opgeleide ouders. Hieronder wordt ingegaan op de extra kwalificaties die de afgestudeerden vóór of tijdens de opleiding eventueel hebben opgedaan (werkervaring, bestuurlijke ervaring, stageervaring en buitenland-ervaring). 
Tabel 2.3

Ervaring opgedaan vóór afstuderen, meting 1997 en 1998

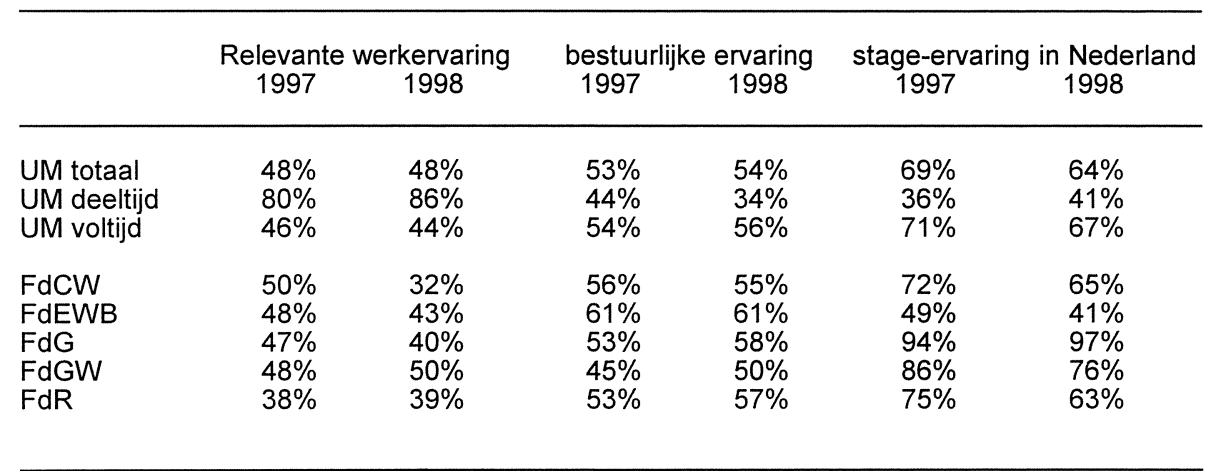

Meerdere antwoorden mogelijk.

\section{Relevante werkervaring}

Zowel in meting 1997 als in meting 1998 is naar voren gekomen dat bijna de helft (48\%) van de afgestudeerden vóór of tijdens de opleiding betaalde of onbetaalde werkervaring (exclusief stages) heeft opgedaan die relevant is voor hun vakgebied. Afgestudeerden van deeltijdopleidingen beschikken bijna twee keer zo vaak over vakrelevante werkervaring als afgestudeerden van voltijdopleidingen (tabel 2.3).

\section{Bestuurlijke ervaring}

Tabel 2.3 laat zien dat iets meer dan de helft van de afgestudeerden vóór of tijdens de opleiding bestuurlijke ervaring heeft opgedaan. Afgestudeerden van deeltijdopleidingen beschikken minder vaak over bestuurlijke ervaring dan afgestudeerden van voltijdopleidingen. Tussen de faculteiten zijn de verschillen met betrekking tot dit kenmerk niet significant.

\section{Stage-ervaring in Nederland}

Bij alle faculteiten, behoudens de FdG, is het aandeel van afgestudeerden met stage-ervaring in Nederland ten opzichte van de vorige meting gedaald. Dit laat onverlet dat nog steeds bijna tweederde (64\%) van de afgestudeerden tijdens de opleiding aan de UM stage heeft gelopen in Nederland (tabel 2.3). Afgestudeerden van voltijdopleidingen beschikken veel vaker over stage-ervaring, opgedaan in Nederland, dan afgestudeerden van deeltijdopleidingen. Laatstgenoemden komen vaker in aanmerking voor vrijstelling voor de stage omdat ze al over vakrelevante werkervaring beschikken. Afgestudeerden van de FdG hebben het vaakst Nederlandse stage-ervaring opgedaan (co-assistentschappen); afgestudeerden van de FdEWB het minst vaak. 


\section{Buitenland-ervaring}

Met de verdergaande Europese eenwording neemt de totstandkoming van één Europese arbeidsmarkt steeds vastere vormen aan. In het licht hiervan staat de internationalisering van het onderwijs, in het bijzonder het hoger onderwijs, hoog op de politieke agenda van niet alleen de Europese Unie en de afzonderlijke lidstaten maar ook de instellingen van hoger onderwijs.

Binnen steeds meer opleidingen voor hoger onderwijs is de internationale oriëntatie van studenten een belangrijk aspect. Het is steeds vaker mogelijk om een deel van de studie, een stage of project in het buitenland te volgen. Daarnaast wordt bij een aantal opleidingen een aanzienlijk deel van het onderwijs in een vreemde taal verzorgd, worden er speciale taaltrainingen aangeboden en internationaal gerichte curricula ontwikkeld. Buitenland-ervaring, opgedaan tijdens de opleiding kan van belang zijn voor de wijze waarop de transitie van universiteit naar werk en de verdere ontwikkeling van de beroepsloopbaan verloopt.

Tabel 2.4

Buitenland-ervaring opgedaan tijdens de opleiding aan de UM, meting 1997 en 1998

\begin{tabular}{|c|c|c|c|c|c|}
\hline & $\begin{array}{r}\text { S } \\
\text { bu } \\
1997\end{array}$ & $\begin{array}{l}\text { in } \\
\text { and } \\
1998\end{array}$ & $\begin{array}{l}\text { studie-onderdeel } \\
\text { in buitenland }\end{array}$ & $\begin{array}{l}\text { andere buiten- } \\
\text { land-ervaring }\end{array}$ & $\begin{array}{l}\text { geen buiten- } \\
\text { land-ervaring }\end{array}$ \\
\hline $\begin{array}{l}\text { UM totaal } \\
\text { UM deeltijd } \\
\text { UM voltijd }\end{array}$ & $\begin{array}{r}25 \% \\
0 \% \\
26 \%\end{array}$ & $\begin{array}{r}22 \% \\
0 \% \\
24 \%\end{array}$ & $\begin{array}{r}19 \% \\
0 \% \\
21 \%\end{array}$ & $\begin{array}{r}11 \% \\
0 \% \\
12 \%\end{array}$ & $\begin{array}{r}61 \% \\
100 \% \\
56 \%\end{array}$ \\
\hline $\begin{array}{l}\text { FdCW } \\
\text { FdEWB } \\
\text { FdG } \\
\text { FdGW } \\
\text { FdR }\end{array}$ & $\begin{array}{r}39 \% \\
24 \% \\
69 \% \\
22 \% \\
9 \%\end{array}$ & $\begin{array}{r}0 \% \\
18 \% \\
56 \% \\
24 \% \\
8 \%\end{array}$ & $\begin{array}{r}10 \% \\
36 \% \\
18 \% \\
7 \% \\
24 \%\end{array}$ & $\begin{array}{r}10 \% \\
18 \% \\
19 \% \\
6 \% \\
8 \%\end{array}$ & $\begin{array}{l}80 \% \\
47 \% \\
33 \% \\
68 \% \\
69 \%\end{array}$ \\
\hline
\end{tabular}

Meerdere antwoorden mogelijk. De vragen naar respectievelijk in het buitenland gevolgde studie-onderdelen, andere buitenland-ervaring en geen buitenland-ervaring zijn voor het eerst gesteld in meting 1998.

De cijfers in tabel 2.4 laten zien dat de meerderheid van afstudeerjaargang 1997 geen buitenland-ervaring heeft opgedaan tijdens de opleiding aan de UM. Dit laat onverlet dat een op de vijf afgestudeerden (22\%, vorige meting $25 \%$ ) in het buitenland stage heeft gelopen, eveneens een op de vijf afgestudeerden (19\%) een studie-onderdeel heeft gevolgd in het buitenland en een op de tien afgestudeerden $(11 \%)$ tijdens de opleiding anderszins buitenland-ervaring heeft opgedaan. Overigens heeft niemand van de afgestudeerden van deeltijdopleidingen tijdens de opleiding aan de UM ervaring in het buitenland opgedaan. Van alle afgestudeerden van voltijdopleidingen hebben afgestudeerden van de $\mathrm{FdG}$ het vaakst in het buitenland stage gelopen en afgestudeerden van de FdEWB het vaakst een onderdeel van hun studie in het buitenland gevolgd. 


\subsection{Kans op werk}

De kans op werk tijdens de arbeidsmarktintrede wordt geschetst aan de hand van achtereenvolgens het totaal aantal maanden dat men tussen het moment van afstuderen en het enquêtemoment werkzoekend is geweest, de mate waarin men op het enquêtemoment beschikbaar is voor de arbeidsmarkt (het procentuele aandeel van afgestudeerden die zich op de arbeidsmarkt aanbieden) en het succes waarmee men zich op het enquêtemoment op de arbeidsmarkt aanbiedt (het procentuele aandeel van afgestudeerden die behoren tot de werkzame beroepsbevolking).

\section{Duur intredewerkloosheid}

Hoe korter de periode van onvrijwillige werkloosheid, hoe beter. Immers, nog afgezien van de sociale en emotionele kosten van onvrijwillige werkloosheid, brengt het niet benutten van arbeidsaanbod economische kosten met zich mee: zowel voor de maatschappij als geheel als voor het betrokken individu. De economische kosten voor de maatschappij betreffen zowel directe kosten (in de vorm van sociale uitkeringen) als indirecte kosten (als gevolg van onvervulde vraag naar arbeid). De economische kosten voor het individu betreffen in de eerste plaats het ontberen van een arbeidsloon. Daarbij kan langdurige werkloosheid leiden tot mogelijke veroudering van de in de opleiding opgebouwde kennis en vaardigheden, tot stigmatisering in de ogen van werkgevers, en daarmee tot een kleinere kans op werk.

De duur van de intredewerkloosheid kan samenhangen met de arbeidsmarktpositie van de gevolgde opleiding. Bij een in verhouding tot het aanbod geringe vraag naar afgestudeerden van een bepaalde opleiding, geeft de duur van de intredewerkloosheid vooral een indicatie van de moeite waarmee afgestudeerden van de desbetreffende opleiding werk vinden. Deze indicator zegt evenwel niets over de kwaliteit van het gevonden werk, bijvoorbeeld of het werk betreft dat aansluit bij het niveau en de richting van de genoten opleiding.

Is de vraag naar afgestudeerden groter dan het aanbod, dan kan de duur van de intredewerkloosheid ook een indicatie zijn van de zoekstrategie van de afgestudeerde. Bij een gespannen arbeidsmarkt kunnen afgestudeerden, indien zij dat willen, vrij gemakkelijk een baan krijgen die zij wellicht iets minder geschikt achten (bijvoorbeeld een tijdelijke baan of een baan die niet past bij het niveau en/of de richting van hun opleiding) om van daar uit te zoeken naar een geschikte baan. Bij een krappe arbeidsmarkt kunnen afgestudeerden het zich dus permitteren om te kiezen tussen 'on the job' (vanuit een baan) en 'off the job' (vanuit een situatie van werkloosheid) zoeken naar een geschikte baan.

Tabel 2.5 laat het aantal maanden zien dat men na het afstuderen in totaal werkzoekend is geweest. De tabel heeft alleen betrekking op afgestudeerden die zich na het verlaten van de UM op enigerlei moment hebben aangeboden op de arbeidsmarkt, dat wil zeggen betaald werk hebben gehad of werkloos zijn geweest. De tabel geeft een indicatie van het succes waarmee men naar betaald werk heeft 
gezocht. Het gaat hier om de totale zoekduur in de genoemde periode, aaneengesloten dan wel onderbroken door eventuele andere bezigheden.

Tabel 2.5

Totaal aantal maanden werkzoekend tussen moment van afstuderen en enquêtemoment, meetjaar 1998

\begin{tabular}{|c|c|c|c|c|}
\hline & 0 mnd. & 1-3 mnd. & 4-6 mnd. & $>6$ mnd. \\
\hline $\begin{array}{l}\text { UM totaal } \\
1997 \\
1998\end{array}$ & $\begin{array}{l}59 \% \\
70 \%\end{array}$ & $\begin{array}{l}22 \% \\
20 \%\end{array}$ & $\begin{array}{r}12 \% \\
6 \%\end{array}$ & $\begin{array}{l}7 \% \\
4 \%\end{array}$ \\
\hline $\begin{array}{l}\text { UM deeltijd } \\
1997 \\
1998\end{array}$ & $\begin{array}{l}91 \% \\
96 \%\end{array}$ & $\begin{array}{l}5 \% \\
0 \%\end{array}$ & $\begin{array}{l}2 \% \\
4 \%\end{array}$ & $\begin{array}{l}2 \% \\
0 \%\end{array}$ \\
\hline $\begin{array}{l}\text { UM voltijd } \\
1997 \\
1998\end{array}$ & $\begin{array}{l}56 \% \\
67 \%\end{array}$ & $\begin{array}{l}24 \% \\
23 \%\end{array}$ & $\begin{array}{r}13 \% \\
6 \%\end{array}$ & $\begin{array}{l}7 \% \\
4 \%\end{array}$ \\
\hline $\begin{array}{l}\text { FdCW } \\
1997 \\
1998\end{array}$ & $\begin{array}{l}32 \% \\
53 \%\end{array}$ & $\begin{array}{l}32 \% \\
27 \%\end{array}$ & $\begin{array}{l}26 \% \\
13 \%\end{array}$ & $\begin{array}{r}11 \% \\
7 \%\end{array}$ \\
\hline $\begin{array}{l}\text { FdEWB } \\
1997 \\
1998\end{array}$ & $\begin{array}{l}63 \% \\
68 \%\end{array}$ & $\begin{array}{l}19 \% \\
21 \%\end{array}$ & $\begin{array}{r}13 \% \\
7 \%\end{array}$ & $\begin{array}{l}5 \% \\
4 \%\end{array}$ \\
\hline $\begin{array}{l}\mathrm{FdG} \\
1997 \\
1998\end{array}$ & $\begin{array}{l}52 \% \\
69 \%\end{array}$ & $\begin{array}{l}34 \% \\
30 \%\end{array}$ & $\begin{array}{r}12 \% \\
1 \%\end{array}$ & $\begin{array}{l}2 \% \\
0 \%\end{array}$ \\
\hline $\begin{array}{l}\text { FdGW } \\
1997 \\
1998\end{array}$ & $\begin{array}{l}52 \% \\
72 \%\end{array}$ & $\begin{array}{l}26 \% \\
15 \%\end{array}$ & $\begin{array}{r}12 \% \\
8 \%\end{array}$ & $\begin{array}{r}10 \% \\
5 \%\end{array}$ \\
\hline $\begin{array}{l}\mathrm{FdR} \\
1997 \\
1998\end{array}$ & $\begin{array}{l}57 \% \\
59 \%\end{array}$ & $\begin{array}{l}22 \% \\
29 \%\end{array}$ & $\begin{array}{r}13 \% \\
7 \%\end{array}$ & $\begin{array}{l}7 \% \\
6 \%\end{array}$ \\
\hline
\end{tabular}

De economische hoogconjunctuur van de laatste jaren heeft er toe bijgedragen dat de duur van de intredewerkloosheid ten opzichte van de vorige meting fors is gedaald. Zo is het aandeel van afgestudeerden die sinds het afstuderen helemaal niet werkzoekend zijn geweest tussen 1997 en 1998 gestegen van 59\% naar 70\%, terwijl het aandeel van afgestudeerden die in totaal langer dan drie maanden naar werk hebben gezocht is gedaald van $19 \%$ naar $10 \%$. Deze ontwikkeling kan bij de afgestudeerden van alle faculteiten worden geconstateerd.

Afgestudeerden van deeltijdopleidingen hebben een veel kleinere kans dan afgestudeerden van voltijdopleidingen om werkzoekend te zijn geweest. Binnen de voltijdopleidingen varieert het aandeel van afgestudeerden die in het geheel niet werkzoekend zijn geweest thans van $53 \%$ bij de FdCW tot $72 \%$ bij de FdGW. 
Tabel 2.6 geeft een indicatie van de mate waarin de afgestudeerden zich, gemeten zo'n anderhalf jaar na het verlaten van de UM, aanbieden op de arbeidsmarkt (behoren tot de beroepsbevolking) en het succes waarmee zij dit doen (behoren tot de werkzame beroepsbevolking). Bij de beslissing om zich al dan niet aan te bieden op de arbeidsmarkt kunnen persoonlijke factoren of individuele verwachtingen omtrent de kans op werk een rol spelen. Zo kunnen afgestudeerden die verwachten niet of moeilijk werk te krijgen er voor kiezen om zich niet aan te bieden op de arbeidsmarkt, maar bijvoorbeeld full-time verder onderwijs te gaan volgen. Op deze wijze hopen zij hun profiel te verbeteren en daarmee hun kans op werk te vergroten. Het is uiteraard ook mogelijk dat afgestudeerden er puur voor hun plezier voor kiezen om verder onderwijs te gaan volgen.

\section{Beroepsbevolking}

De beroepsbevolking bestaat uit enerzijds mensen die zich met succes hebben aangeboden op de arbeidsmarkt (werkzame personen) en anderzijds werklozen (mensen die zich vooralsnog zonder succes aanbieden op de arbeidsmarkt).

Gezien vanuit de samenleving mag worden gesteld: hoe groter het aandeel van de beroepsbevolking (ofwel afgestudeerden die zich aanbieden op de arbeidsmarkt), hoe beter. Immers, het is legitiem om te veronderstellen dat het economisch rendement op de maatschappelijke investering in onderwijs in potentie toeneemt naarmate meer afgestudeerden zich op de arbeidsmarkt aanbieden. Gezien vanuit het individu kan het al dan niet aanbieden op de arbeidsmarkt mede samenhangen met hoe hij of zij het genoten onderwijs beschouwt: als consumptiegoed of als investeringsgoed. In het eerste geval (onderwijs als consumptiegoed) is de vraag van wel of niet aanbieden niet relevant. In het laatste geval (onderwijs als investering) kan de investering alleen renderend worden gemaakt door zich op de arbeidsmarkt aan te bieden teneinde loon uit arbeid te genereren.

Tot de beroepsbevolking behoren - conform de definitie van het Centraal Bureau voor de Statistiek (CBS) - afgestudeerden die tenminste 12 uur per week betaald werken, afgestudeerden die werk hebben aanvaard waardoor zij tenminste 12 uur per week betaald gaan werken en afgestudeerden die tenminste 12 uur per week willen werken, daarvoor beschikbaar zijn en daartoe tevens activiteiten ontplooien. $\mathrm{Bij}$ het aandeel van de beroepsbevolking dient te worden opgemerkt dat, in afwijking van de door het CBS gehanteerde definitie van de beroepsbevolking, afgestudeerden die te kennen geven dat zij in eerste instantie 'student' zijn (ook al zijn zij formeel werkend of werkloos) niet tot de beroepsbevolking worden gerekend. Hiermee wordt voorkomen dat de arbeidsmarktpositie van een opleiding mede wordt afgemeten aan de groep die gaat verder leren.

Tabel 2.6 laat zien dat, gemeten zo'n anderhalf jaar na het verlaten van de universiteit, vrijwel alle (94\%) afgestudeerden van de UM zich op de arbeidsmarkt aanbieden; dat wil zeggen tot de beroepsbevolking behoren. Wat dit kenmerk betreft, verschillen afgestudeerden van deeltijdopleidingen niet significant van afgestu- 
deerden van voltijdopleidingen. Afgestudeerden cultuurwetenschappen zijn vaker dan andere afgestudeerden niet beschikbaar voor de arbeidsmarkt. Overigens kan bij alle faculteiten worden geconstateerd dat het aandeel van afgestudeerden die zich aanbieden op de arbeidsmarkt ten opzichte van de vorige meting licht is gedaald.

Tabel 2.6

Arbeidsmarktparticipatie op enquêtemoment, meting 1997 en 1998

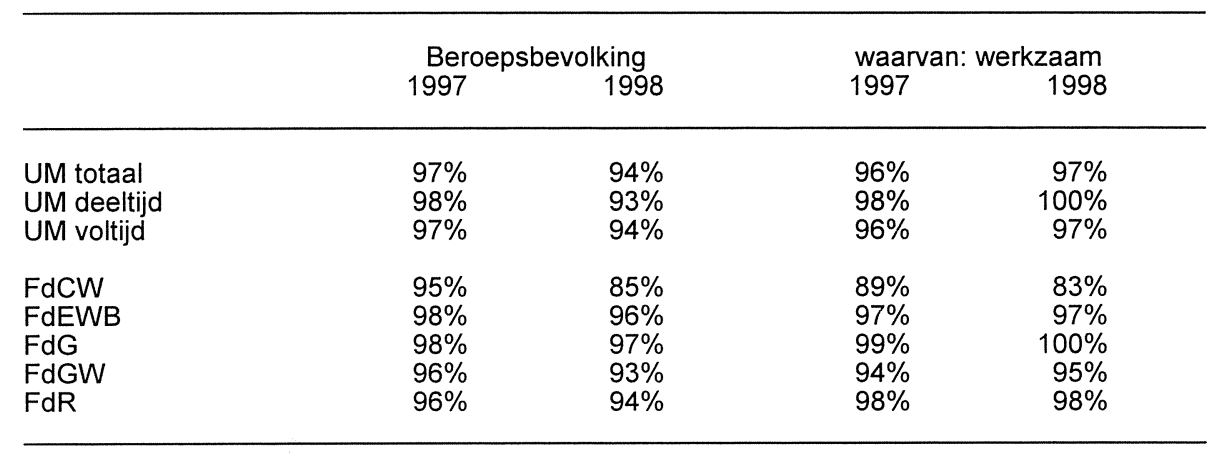

\section{Werkzame personen}

Zoals eerder is gezegd, bestaat de beroepsbevolking uit enerzijds mensen die zich met succes hebben aangeboden op de arbeidsmarkt (werkzame personen) en anderzijds werklozen (mensen die zich vooralsnog zonder succes aanbieden op de arbeidsmarkt). Het aandeel in de beroepsbevolking van werkzame personen vormt derhalve een indicator voor het succes waarmee men zich aanbiedt op de arbeidsmarkt: succes in de betekenis van kans op werk. Deze indicator zegt evenwel niets over de kwaliteit van het gevonden werk.

Welnu, de cijfers in tabel 2.6 laten zien dat vrijwel alle (97\%, vorige meting 96\%) afgestudeerden van de UM die zich op de arbeidsmarkt aanbieden dit met succes doen. Hierbij doen zich geen significante verschillen voor tussen de afgestudeerden van deeltijdopleidingen en de afgestudeerden van voltijdopleidingen. Afgestudeerden van de FdCW bieden zich met minder succes aan op de arbeidsmarkt dan afgestudeerden van de andere faculteiten.

\subsection{Kwaliteit van het werk}

De kwaliteit van het werk dat de betaald-werkende afgestudeerden zo'n anderhalf jaar na het verlaten van de UM uitoefenen, wordt geschetst aan de hand van achtereenvolgens de aard van het dienstverband, de zekerheid van het werk en de aansluiting van het werk naar het niveau en de richting van de gevolgde opleiding. 


\section{Aard van het dienstverband}

Het soort dienstverband is indicatief voor de rechtspositie van de betaald-werkenden. Hierbij kan een hoofdonderscheid worden gemaakt tussen degenen die als zelfstandige of freelancer zelf in hun werkgelegenheid voorzien en degenen die op grond van een arbeidsovereenkomst werkzaam zijn. Overigens kan in een arbeidsovereenkomst de verplichting tot het volgen van een opleiding zijn opgenomen, bijvoorbeeld als $\mathrm{AIO}$ of $\mathrm{OIO}$.

Van de betaald-werkende afgestudeerden werkt de overgrote meerderheid in loondienst bij een werkgever; $6 \%$ werkt als uitzend- of oproepkracht en 'slechts' $1 \%$ als freelancer of als zelfstandige in een eigen bedrijf of praktijk. Ten opzichte van de vorige meting is het aandeel van afgestudeerden die werken als uitzend-, oproep- of invalkracht toegenomen ten koste van de in reguliere loondienst werkende afgestudeerden (dit betreft in hoofdzaak afgestudeerden van de FdCW, FdGW en $\mathrm{FdR})$.

Tabel 2.7 toont verder dat niemand van de afgestudeerden van deeltijdopleidingen als zelfstandige of freelancer is gaan werken. Vergeleken met afgestudeerden van deeltijdopleidingen werken afgestudeerden van voltijdopleidingen iets vaker als uitzend- of oproepkracht. Van alle afgestudeerden werken de afgestudeerden van de FdEWB het vaakst in loondienst, en afgestudeerden cultuurwetenschappen het vaakst als uitzend- of oproepkracht.

Tabel 2.7

Aard van het dienstverband, meting 1997 en 1998

\begin{tabular}{|c|c|c|c|c|}
\hline & Loondienst & $\begin{array}{l}\text { uitzend-, oproep- } \\
\text { invalkracht }\end{array}$ & $\begin{array}{l}\text { zelfstandige/ } \\
\text { freelance }\end{array}$ & $\begin{array}{c}\text { ander } \\
\text { dienstverband }\end{array}$ \\
\hline $\begin{array}{l}\text { UM totaal } \\
1997 \\
1998\end{array}$ & $\begin{array}{l}94 \% \\
88 \%\end{array}$ & $\begin{array}{l}1 \% \\
6 \%\end{array}$ & $\begin{array}{l}1 \% \\
1 \%\end{array}$ & $\begin{array}{l}4 \% \\
5 \%\end{array}$ \\
\hline $\begin{array}{l}\text { UM deeltijd } \\
1997 \\
1998\end{array}$ & $\begin{array}{l}98 \% \\
94 \%\end{array}$ & $\begin{array}{l}0 \% \\
2 \%\end{array}$ & $\begin{array}{l}0 \% \\
0 \%\end{array}$ & $\begin{array}{l}2 \% \\
4 \%\end{array}$ \\
\hline $\begin{array}{l}\text { UM voltijd } \\
1997 \\
1998\end{array}$ & $\begin{array}{l}94 \% \\
87 \%\end{array}$ & $\begin{array}{l}1 \% \\
7 \%\end{array}$ & $\begin{array}{l}1 \% \\
1 \%\end{array}$ & $\begin{array}{l}4 \% \\
5 \%\end{array}$ \\
\hline $\begin{array}{l}\text { FdCW } \\
1997 \\
1998\end{array}$ & $\begin{array}{l}81 \% \\
71 \%\end{array}$ & $\begin{array}{r}0 \% \\
21 \%\end{array}$ & $\begin{array}{r}13 \% \\
0 \%\end{array}$ & $\begin{array}{l}6 \% \\
7 \%\end{array}$ \\
\hline $\begin{array}{l}\text { FdEWB } \\
1997 \\
1998\end{array}$ & $\begin{array}{l}97 \% \\
94 \%\end{array}$ & $\begin{array}{l}0 \% \\
2 \%\end{array}$ & $\begin{array}{l}0 \% \\
2 \%\end{array}$ & $\begin{array}{l}2 \% \\
2 \%\end{array}$ \\
\hline $\begin{array}{l}\text { FdG } \\
1997 \\
1998\end{array}$ & $\begin{array}{l}92 \% \\
86 \%\end{array}$ & $\begin{array}{l}1 \% \\
3 \%\end{array}$ & $\begin{array}{l}0 \% \\
1 \%\end{array}$ & $\begin{array}{r}7 \% \\
10 \%\end{array}$ \\
\hline
\end{tabular}




\begin{tabular}{lcccc}
\hline & Loondienst & $\begin{array}{c}\text { uitzend-, oproep- } \\
\text { invalkracht }\end{array}$ & $\begin{array}{c}\text { zelfstandige/ } \\
\text { freelance }\end{array}$ & $\begin{array}{c}\text { ander } \\
\text { dienstverband }\end{array}$ \\
\hline FdGW & & & \\
1997 & $91 \%$ & $2 \%$ & $2 \%$ & $5 \%$ \\
1998 & $84 \%$ & $11 \%$ & $0 \%$ & $6 \%$ \\
FdR & & & & \\
1997 & $96 \%$ & $0 \%$ & $3 \%$ & $1 \%$ \\
1998 & $83 \%$ & $11 \%$ & $2 \%$ & $4 \%$ \\
\hline
\end{tabular}

\section{Werkzekerheid}

Zo'n anderhalf jaar na het verlaten van de UM is ongeveer de helft (49\%) van de betaald-werkende afgestudeerden al in een vaste aanstelling (incl. proeftijd voor een vaste aanstelling) of een aanstelling voor onbepaalde tijd werkzaam (tabel 2.8). Een kwart $(24 \%)$ werkt weliswaar vooralsnog in een tijdelijke aanstelling, maar heeft wel uitzicht op een vaste aanstelling. Ruim een kwart (27\%) van de betaald-werkende afgestudeerden heeft een tijdelijke aanstelling, zonder uitzicht op een vaste aanstelling.

Bij een tijdelijke aanstelling maakt het overigens veel uit om welk soort baan het gaat: een tijdelijk uitzendbaantje of een per definitie tijdelijke opleidingsplaats voor bijvoorbeeld AIO of medisch specialist. Ten opzichte van meting 1997 is de werkzekerheid in 1998 iets gedaald: het aandeel van tijdelijke aanstellingen zónder uitzicht op een vaste aanstelling is licht gestegen ten koste van de tijdelijke aanstellingen mét uitzicht op een vaste aanstelling.

Afgestudeerden van deeltijdopleidingen hebben bijna twee keer zo vaak een vaste aanstelling als afgestudeerden van voltijdopleidingen: wellicht werken afgestudeerden van deeltijdopleidingen vaak nog steeds in dezelfde baan die zij al tijdens hun opleiding hadden.

Wat de verschillen tussen de voltijdopleidingen betreft, blijkt dat afgestudeerden van de FdEWB het vaakst en afgestudeerden cultuurwetenschappen en geneeskunde het minst vaak een vaste aanstelling hebben. Dat afgestudeerden geneeskunde vaker dan anderen een tijdelijke aanstelling zonder uitzicht op een vaste aanstelling hebben, kan deels worden verklaard uit het gegeven dat basisartsen vaak gaan werken in een, per definitie, tijdelijke opleidingsplaats voor medisch specialist. Afgestudeerden van de FdR en FdCW hebben vaker dan afgestudeerden van de andere faculteiten een vooralsnog tijdelijke aanstelling, maar wel met uitzicht op een vaste aanstelling. 
Tabel 2.8

Soort aanstelling, meting 1997 en 1998

\begin{tabular}{|c|c|c|c|}
\hline & Vast/proeftijd & $\begin{array}{l}\text { met uitzicht } \\
\text { op vast }\end{array}$ & $\begin{array}{c}\text { zonder uitzicht } \\
\text { op vast }\end{array}$ \\
\hline $\begin{array}{l}\text { UM totaal } \\
1997 \\
1998\end{array}$ & $\begin{array}{l}49 \% \\
49 \%\end{array}$ & $\begin{array}{l}27 \% \\
24 \%\end{array}$ & $\begin{array}{l}24 \% \\
27 \%\end{array}$ \\
\hline $\begin{array}{l}\text { UM deeltijd } \\
1997 \\
1998\end{array}$ & $\begin{array}{l}87 \% \\
87 \%\end{array}$ & $\begin{array}{r}7 \% \\
11 \%\end{array}$ & $\begin{array}{l}6 \% \\
2 \%\end{array}$ \\
\hline $\begin{array}{l}\text { UM voltijd } \\
1997 \\
1998\end{array}$ & $\begin{array}{l}46 \% \\
45 \%\end{array}$ & $\begin{array}{l}29 \% \\
26 \%\end{array}$ & $\begin{array}{l}25 \% \\
30 \%\end{array}$ \\
\hline $\begin{array}{l}\text { FdCW } \\
1997 \\
1998\end{array}$ & $\begin{array}{l}29 \% \\
21 \%\end{array}$ & $\begin{array}{l}21 \% \\
36 \%\end{array}$ & $\begin{array}{l}50 \% \\
43 \%\end{array}$ \\
\hline $\begin{array}{l}\text { FdEWB } \\
1997 \\
1998\end{array}$ & $\begin{array}{l}66 \% \\
70 \%\end{array}$ & $\begin{array}{l}28 \% \\
21 \%\end{array}$ & $\begin{array}{r}6 \% \\
10 \%\end{array}$ \\
\hline $\begin{array}{l}\mathrm{FdG} \\
1997 \\
1998\end{array}$ & $\begin{array}{l}17 \% \\
20 \%\end{array}$ & $\begin{array}{l}15 \% \\
16 \%\end{array}$ & $\begin{array}{l}69 \% \\
64 \%\end{array}$ \\
\hline $\begin{array}{l}\text { FdGW } \\
1997 \\
1998\end{array}$ & $\begin{array}{l}35 \% \\
35 \%\end{array}$ & $\begin{array}{l}27 \% \\
25 \%\end{array}$ & $\begin{array}{l}38 \% \\
40 \%\end{array}$ \\
\hline $\begin{array}{l}\text { FdR } \\
1997 \\
1998\end{array}$ & $\begin{array}{l}47 \% \\
47 \%\end{array}$ & $\begin{array}{l}40 \% \\
42 \%\end{array}$ & $\begin{array}{l}13 \% \\
11 \%\end{array}$ \\
\hline
\end{tabular}

Aansluiting opleiding-werk naar niveau

De meerderheid van de afgestudeerden heeft werk gevonden waarvoor een opleiding op universitair niveau is vereist (tabel 2.9). Dit laat onverlet dat eenderde werkt in een functie die ook door een opgeleide op HBO-niveau mag worden vervuld. Als relativerende kanttekening dient te worden vermeld dat de grenzen tussen functies op universitair niveau en functies op HBO-niveau vloeiender verlopen dan de grenzen tussen functies op HBO-niveau en functies op MBOniveau. Zo wordt vaak voor functies geworven met als vereist opleidingsniveau HBO of WO. Deze functies worden dan benoemd als functies op (minimaal) HBO-niveau. Daarbij komt dat een functie op HBO-niveau door een universitair opgeleide na verloop van tijd op een hoger, dat wil zeggen meer academisch niveau, kan worden vervuld dan door een HBO'er. Benutting van dat hogere opleidingsniveau zou dan in een hoger loon tot uiting moeten komen. Dit blijkt inderdaad het geval te zijn. Zo 
komt uit onderzoek naar voren dat universitair opgeleiden in functies op HBO-niveau meer verdienen dan $\mathrm{HBO}^{\prime} \mathrm{ers}^{2}$.

Afgestudeerden van deeltijdopleidingen hebben vaker functies op HBO-niveau dan afgestudeerden van voltijdopleidingen. Hierbij kan een rol spelen dat afgestudeerden van deeltijdopleidingen vaak nog steeds in dezelfde HBO-baan werken die zij al tijdens hun opleiding aan de UM hadden.

Tabel 2.9

Door werkgever vereist opleidingsniveau, meting 1997 en 1998

\begin{tabular}{|c|c|c|c|}
\hline & WO-niveau & HBO-niveau & $\begin{array}{c}\text { lager dan } \\
\text { HBO-niveau }\end{array}$ \\
\hline $\begin{array}{l}\text { UM totaal } \\
1997 \\
1998\end{array}$ & $\begin{array}{l}60 \% \\
63 \%\end{array}$ & $\begin{array}{l}35 \% \\
33 \%\end{array}$ & $\begin{array}{l}5 \% \\
4 \%\end{array}$ \\
\hline $\begin{array}{l}\text { UM deeltijd } \\
1997 \\
1998\end{array}$ & $\begin{array}{l}28 \% \\
38 \%\end{array}$ & $\begin{array}{l}61 \% \\
56 \%\end{array}$ & $\begin{array}{r}11 \% \\
6 \%\end{array}$ \\
\hline $\begin{array}{l}\text { UM voltijd } \\
1997 \\
1998\end{array}$ & $\begin{array}{l}62 \% \\
66 \%\end{array}$ & $\begin{array}{l}33 \% \\
30 \%\end{array}$ & $\begin{array}{l}5 \% \\
4 \%\end{array}$ \\
\hline $\begin{array}{l}\text { FdCW } \\
1997 \\
1998\end{array}$ & $\begin{array}{l}88 \% \\
14 \%\end{array}$ & $\begin{array}{r}6 \% \\
64 \%\end{array}$ & $\begin{array}{r}6 \% \\
21 \%\end{array}$ \\
\hline $\begin{array}{l}\text { FdEWB } \\
1997 \\
1998\end{array}$ & $\begin{array}{l}49 \% \\
58 \%\end{array}$ & $\begin{array}{l}47 \% \\
39 \%\end{array}$ & $\begin{array}{l}5 \% \\
3 \%\end{array}$ \\
\hline $\begin{array}{l}\text { FdG } \\
1997 \\
1998\end{array}$ & $\begin{array}{l}100 \% \\
100 \%\end{array}$ & $\begin{array}{l}0 \% \\
0 \%\end{array}$ & $\begin{array}{l}0 \% \\
0 \%\end{array}$ \\
\hline $\begin{array}{l}\text { FdGW } \\
1997 \\
1998\end{array}$ & $\begin{array}{l}53 \% \\
52 \%\end{array}$ & $\begin{array}{l}40 \% \\
41 \%\end{array}$ & $\begin{array}{l}7 \% \\
6 \%\end{array}$ \\
\hline $\begin{array}{l}\mathrm{FdR} \\
1997 \\
1998\end{array}$ & $\begin{array}{l}72 \% \\
71 \%\end{array}$ & $\begin{array}{l}22 \% \\
24 \%\end{array}$ & $\begin{array}{l}6 \% \\
5 \%\end{array}$ \\
\hline
\end{tabular}

Tabel 2.9 toont verder dat het aandeel van niveau-passend werk ten opzichte van de vorige meting onder afgestudeerden van de FdEWB fors is toegenomen en onder afgestudeerden van de FdCW fors is gedaald. Met betrekking tot de FdCW mag evenwel aan de op het eerste gezicht 'dramatische' daling geen al te groot gewicht worden toegekend, gezien de nog zeer kleine aantallen afgestudeerden waarop de cijfers betrekking hebben.

2. Zie bijvoorbeeld: Welters, R.A.M.H.M., E.J.T.A. Willems, R.K.W. van der Velden, (1998), Economen op de arbeidsmarkt 1997. WO-Monitor Economie, ROA-R-1999/2, Researchcentrum voor Onderwijs en Arbeidsmarkt, Maastricht. 
Wat de verschillen tussen de voltijdopleidingen betreft, blijkt dat afgestudeerden van de FdG zonder uitzondering werk vinden dat past bij hun opleidingsniveau. Afgestudeerden van de $\mathrm{FdCW}$ vinden het vaakst werk op minimaal $\mathrm{HBO}$-niveau en bovendien vaker dan afgestudeerden van de andere faculteiten werk onder HBOniveau.

\section{Aansluiting opleiding-werk naar richting}

Volgens de job matching theorie ${ }^{3}$ is de bruikbaarheid van iemands competenties context-specifiek. Dat wil zeggen dat iemands productieve waarde niet alleen afhangt van zijn of haar specifieke competenties maar ook van de specifieke functie waarbinnen deze competenties zijn vereist. Op basis van deze theorie mag worden verwacht dat binnen hun eigen beroepsdomein afgestudeerden meer productieve waarde, geïndiceerd door een hoger loon, hebben dan afgestudeerden voor wie dit niet het eigen beroepsdomein is. Van het eigen beroepsdomein is sprake indien voor de functie de eigen of een daaraan verwante opleidingsrichting door de werkgever werd vereist.

De cijfers in tabel 2.10 tonen dat ruim driekwart (77\%) van de betaald-werkende afgestudeerden werk heeft dat aansluit bij de gevolgde opleidingsrichting. Een op de vijf afgestudeerden (19\%) heeft werk waarvoor aan een specifieke vakrichting gerelateerde kennis en vaardigheden niet zijn vereist. Afgestudeerden van voltijdopleidingen hebben vaker dan afgestudeerden van deeltijdopleidingen werk waar uitsluitend de 'eigen' specifieke opleidingsrichting toegang tot verschaft.

Tabel 2.10

Door werkgever vereiste opleidingsrichting, meting 1997 en 1998

\begin{tabular}{lcccc}
\hline & $\begin{array}{c}\text { Uitsluitend eigen } \\
\text { studierichting }\end{array}$ & $\begin{array}{c}\text { eigen/verwante } \\
\text { studierichting }\end{array}$ & $\begin{array}{c}\text { geheel andere } \\
\text { studierichting }\end{array}$ & $\begin{array}{c}\text { geen specifieke } \\
\text { studierichting }\end{array}$ \\
\hline UM totaal & & & & \\
1997 & $29 \%$ & $51 \%$ & $4 \%$ & $16 \%$ \\
1998 & $33 \%$ & $44 \%$ & $4 \%$ & $19 \%$ \\
UM deeltijd & & & & \\
1997 & $26 \%$ & $57 \%$ & $13 \%$ & $4 \%$ \\
1998 & $17 \%$ & $56 \%$ & $6 \%$ & $22 \%$ \\
UM voltijd & & & & \\
1997 & $29 \%$ & $51 \%$ & $3 \%$ & $17 \%$ \\
1998 & $35 \%$ & $43 \%$ & $4 \%$ & \\
FdCW & & & & \\
1997 & $7 \%$ & $73 \%$ & $0 \%$ & $43 \%$ \\
1998 & $0 \%$ & $36 \%$ & $21 \%$ &
\end{tabular}

3. Voor een overzicht zie: Sattinger, M. (1993), Assignment Models of the Distribution of Earnings, Journal of Economic Literature, Nr. 31, juni, blz. 831-880. 
Tabel 2.10 (vervolg)

Door werkgever vereiste opleidingsrichting, meting 1997 en 1998

\begin{tabular}{lcccc}
\hline & $\begin{array}{c}\text { Uitsluitend eigen } \\
\text { studierichting }\end{array}$ & $\begin{array}{c}\text { eigen/verwante } \\
\text { studierichting }\end{array}$ & $\begin{array}{c}\text { geheel andere } \\
\text { studierichting }\end{array}$ & $\begin{array}{c}\text { geen specifieke } \\
\text { studierichting }\end{array}$ \\
\hline FdEWB & & & & \\
1997 & $12 \%$ & $61 \%$ & $2 \%$ & $25 \%$ \\
1998 & $16 \%$ & $57 \%$ & $0 \%$ & $27 \%$ \\
FdG & & & & \\
1997 & $94 \%$ & $2 \%$ & $0 \%$ & $3 \%$ \\
1998 & $97 \%$ & $3 \%$ & $0 \%$ & $0 \%$ \\
FdGW & & & & \\
1997 & $10 \%$ & $69 \%$ & $7 \%$ & $14 \%$ \\
1998 & $16 \%$ & $59 \%$ & $8 \%$ & $17 \%$ \\
FdR & & & & \\
1997 & $43 \%$ & $37 \%$ & $4 \%$ & $23 \%$ \\
1998 & $37 \%$ & $36 \%$ & $4 \%$ & $2 \%$ \\
\hline
\end{tabular}

Het arbeidsmarktsegment van afgestudeerden van de FdG kan worden getypeerd als een vakdeelmarkt: vrijwel alle basisartsen oefenen functies uit waar uitsluitend de opleiding geneeskunde toegang tot verschaft. Afgestudeerden van vooral de FdGW en FdEWB waaieren wat breder uit over de arbeidsmarkt: zij komen vaak terecht in functies die ook door afgestudeerden van verwante opleidingen zouden kunnen worden vervuld. Afgestudeerden van de FdR nemen wat dit kenmerk betreft een tussenpositie in. Afgestudeerden van de $\mathrm{FdCW}$ hebben relatief vaak algemene functies, dat wil zeggen functies waarvoor een specifieke opleidingsrichting niet is vereist.

\subsection{Loopbaanperspectieven}

Eenmalig zijn in meting 1997 een drietal vragen aan betaald-werkende afgestudeerden voorgelegd, die betrekking hebben op de ontwikkelingsmogelijkheden die hun werkkring biedt.

\section{Ontwikkelingsmogelijkheden van de functie}

Eerst is aan de afgestudeerden de volgende vraag voorgelegd: "Biedt uw huidige functie volgens $u$ voldoende mogelijkheden om u zelf verder te ontwikkelen?". Zij konden hierbij kiezen uit een van de volgende vier antwoordmogelijkheden:

- ja, binnen het bedrijf of de organisatie waar ik nu werk;

- ja, maar in een ander bedrijf of organisatie dan waar ik nu werk;

- ja, zowel binnen het bedrijf of de organisatie waar ik nu werk als in een ander bedrijf of organisatie;

- nee.

Tabel 2.11 geeft de procentuele verdeling van de respondenten over deze antwoordmogelijkheden en laat zien dat negen op de tien afgestudeerden vinden dat hun 
huidige functie voldoende mogelijkheden biedt om zichzelf verder te ontwikkelen. lets meer dan de helft ziet zelfs ontwikkelingsmogelijkheden in niet alleen de huidige organisatie maar ook in andere organisaties. Afgestudeerden van voltijdopleidingen schatten de flexibiliteit van hun huidige functie hoger in dan afgestudeerde deeltijders die vaker geen ontwikkelingsmogelijkheden in hun huidige functie zien.

Tabel 2.11

Ontwikkelingsmogelijkheden van huidige functie, meting 1997

\begin{tabular}{lcccc}
\hline & \multicolumn{2}{c}{$\begin{array}{c}\text { Ja, ontwikkelingsmogelijkheden: } \\
\text { binnen huidige én } \\
\text { in andere } \\
\text { organisatie } \\
\text { organisatie }\end{array}$} & $\begin{array}{l}\text { nee, geen } \\
\text { andere organisatie } \\
\text { ontwikkelings- } \\
\text { mogelijkheden }\end{array}$ \\
\hline UM totaal & $26 \%$ & $10 \%$ & $53 \%$ & $11 \%$ \\
UM deeltijd & $26 \%$ & $6 \%$ & $44 \%$ & $24 \%$ \\
UM voltijd & $26 \%$ & $10 \%$ & $54 \%$ & $10 \%$ \\
FdCW & $38 \%$ & $6 \%$ & $50 \%$ & $6 \%$ \\
FdEWB & $28 \%$ & $8 \%$ & $57 \%$ & $6 \%$ \\
FdG & $26 \%$ & $22 \%$ & $44 \%$ & $15 \%$ \\
FdGW & $24 \%$ & $7 \%$ & $54 \%$ & $10 \%$ \\
FdR & $26 \%$ & $10 \%$ & $54 \%$ & \\
\hline
\end{tabular}

Wat de verschillen tussen de faculteiten betreft, valt op dat cultuurwetenschappers vaker dan anderen ontwikkelingsmogelijkheden binnen hun huidige werkkring zien. Basisartsen zien relatief vaak dat de mogelijkheden voor hun verdere ontwikkeling vooral liggen in een ander bedrijf of organisatie dan waar zij thans werkzaam zijn. Gezondheidswetenschappers vinden iets vaker dan afgestudeerden van andere faculteiten dat hun huidige functie geen verdere ontwikkelingsmogelijkheden biedt.

\section{Loopbaan bij huidige organisatie}

De tweede vraag met betrekking tot het thema loopbaan die aan de betaaldwerkende afgestudeerden is voorgelegd, luidde: "Denkt u dat u over één jaar nog bij het bedrijf of de organisatie werkt waar u nu werkt?". Deze vraag is door bijna driekwart van de afgestudeerden bevestigend beantwoord (tabel 2.12). Van alle afgestudeerden denken basisartsen het minst vaak dat zij over één jaar nog steeds bij hun huidige bedrijforganisatie werkzaam zullen zijn. Afgestudeerden van de andere faculteiten zien hun onmiddellijke loopbaan vaker binnen hun huidige werkkring liggen.

\section{Promotiekansen op korte termijn}

Met betrekking tot het thema loopbaan luidde de laatste vraag die aan de betaaldwerkende afgestudeerden is voorgelegd: "Denkt $u$ dat u binnen één jaar promotie maakt naar een hogere functie?". Hoewel bijna driekwart van de afgestudeerden denkt over één jaar nog steeds bij hun huidige bedrijf/organisatie werkzaam te zullen zijn, verwacht 'slechts' eenderde in die periode te promoveren naar een hogere functie (tabel 2.12). Afgestudeerden van deeltijdopleidingen zijn wat dit betreft 
pessimistischer dan afgestudeerden van voltijdopleidingen, die vaker verwachten binnen één jaar door te stromen naar een hogere functie. Van alle afgestudeerden zijn economen het meest en cultuurwetenschappers het minst optimistisch over hun promotiekansen op korte termijn.

Tabel 2.12

Loopbaanverwachtingen op korte termijn, meting 1997

\begin{tabular}{lcc}
\hline & \multicolumn{2}{c}{$\begin{array}{c}\text { Afgestudeerde verwacht: } \\
\text { binnen één jaar te promoveren } \\
\text { naar een hogere functie }\end{array}$} \\
& $\begin{array}{l}\text { over één jaar nog in zelfde } \\
\text { bedrijf/organisatie te werken }\end{array}$ & $34 \%$ \\
UM totaal & $72 \%$ & $11 \%$ \\
UM deeltijd & $82 \%$ & $36 \%$ \\
UM voltijd & $71 \%$ & $13 \%$ \\
FdCW & $69 \%$ & $56 \%$ \\
FdEWB & $76 \%$ & $23 \%$ \\
FdG & $57 \%$ & $20 \%$ \\
FdGW & $71 \%$ & $33 \%$ \\
FdR & $74 \%$ &
\end{tabular}

\subsection{Oordeel over het werk}

Hieronder wordt eerst beschreven hoe de betaald-werkende afgestudeerden het werk beoordelen, dat zij op het moment van enquêteren uitoefenen. Daarna wordt nagegaan welke waarde afgestudeerden (ook degenen die op het moment van enquêteren geen betaald werk uitoefenen) in het algemeen toekennen aan 'werken'. Deze vragen zijn eenmalig opgenomen in meting 1998.

Oordeel over het huidige werk

Aan de betaald-werkende afgestudeerden van cohort 1997 is achtereenvolgens gevraagd:

- hoe hun huidige functie aansluit op de gevolgde opleiding (gemeten op een vierpuntschaal van 'goed' tot 'slecht');

- hoe tevreden zij in het algemeen zijn over hun huidige werk (gemeten op een vijfpuntschaal van 'zeer ontevreden' tot 'zeer tevreden');

- of hun huidige werk voldoet aan de verwachtingen die zij daaromtrent tijdens hun opleiding hadden (gemeten op een vijfpuntschaal van 'helemaal niet' tot 'helemaal wel').

In tabel 2.13 staat achtereenvolgens vermeld: het procentuele aandeel van de betaald-werkende afgestudeerden die de aansluiting goed of voldoende vinden, het procentuele aandeel van de betaald-werkende afgestudeerden die tevreden of zeer tevreden zijn over hun werk en het procentuele aandeel van de betaald-werkende afgestudeerden die vinden dat het werk (helemaal) voldoet aan hun verwachtingen. 
De meerderheid van de afgestudeerden kwalificeert de aansluiting van het gevonden werk op de gevolgde opleiding als goed of voldoende en is tevreden over het gevonden werk in het algemeen. Bij de meesten voldoet het gevonden werk ook aan de verwachtingen omtrent werk die zij al tijdens hun opleiding hadden. Ten aanzien van deze kenmerken zijn er geen significante verschillen tussen de afgestudeerden van deeltijdopleidingen en de afgestudeerden van voltijdopleidingen.

Tabel 2.13

Oordeel over het huidige werk, meting 1998

\begin{tabular}{lccc}
\hline & $\begin{array}{l}\text { Werk sluit } \\
\text { goed/voldoende } \\
\text { aan op opleiding }\end{array}$ & $\begin{array}{l}\text { (zeer) tevreden } \\
\text { over werk }\end{array}$ & $\begin{array}{l}\text { werk voldoet } \\
\text { (helemaal) aan } \\
\text { verwachtingen }\end{array}$ \\
\hline UM totaal & $82 \%$ & $74 \%$ & $61 \%$ \\
UM deeltijd & $71 \%$ & $65 \%$ & $57 \%$ \\
UM voltijd & $83 \%$ & $75 \%$ & $62 \%$ \\
FdCW & $43 \%$ & $57 \%$ & $29 \%$ \\
FdEWB & $86 \%$ & $83 \%$ & $62 \%$ \\
FdG & $99 \%$ & $83 \%$ & $85 \%$ \\
FdGW & $73 \%$ & $64 \%$ & $69 \%$ \\
FdR & $82 \%$ & $73 \%$ & $62 \%$ \\
\hline
\end{tabular}

Overigens varieert de algemene tevredenheid over het gevonden werk sterk met de aansluiting van het werk op de opleiding: degenen bij wie de functie goed of voldoende aansluit op de opleiding zijn bijna twee keer vaker tevreden over hun werk dan degenen bij wie de functie matig of slecht aansluit op de opleiding, namelijk $80 \%$ versus $44 \%$.

Van alle afgestudeerden van voltijdopleidingen zijn afgestudeerden cultuurwetenschappen het minst vaak tevreden over de aansluiting van het gevonden werk op hun opleiding en over hun werk in het algemeen. Ook voldoet het gevonden werk bij hen het minst vaak aan hun verwachtingen. Zij hebben dan ook het vaakst werk dat niet past bij het niveau (tabel 2.9) en de richting (tabel 2.10) van hun opleiding.

Waarde die in het algemeen wordt toegekend aan werk

Aan alle afgestudeerden - dus ook aan degenen die geen betaald werk verrichten zijn 12 aspecten voorgelegd, die verbonden zijn aan 'werken in het algemeen'. De afgestudeerden is gevraagd om, los van hun huidige situatie, voor elk aspect aan te geven hoe belangrijk zij dit in het algemeen vinden. Zij konden het belang aangeven op een vijfpuntschaal, variërend van 'zeer onbelangrijk' tot 'zeer belangrijk'. Tabel 2.14 toont per aspect het procentuele aandeel van de afgestudeerden die te kennen hebben gegeven dat zij het desbetreffende aspect van 'werk' belangrijk of zeer belangrijk vinden. 
Tenminste $90 \%$ van alle afgestudeerden vindt afwisseling, zelfstandigheid, uitdaging en omgaan met collega's belangrijke aspecten van werken. Tussen de $80 \%$ en $90 \%$ vindt dat verantwoordelijkheid, verdere ontwikkeling van expertise en creativiteit belangrijk zijn in het werk. De aspecten erkenning door anderen, werkzekerheid, combineren van werk met privéleven, maatschappelijke relevantie van het werk alsmede hoog inkomen scoren iets minder hoog in belangrijkheid, hoewel deze aspecten toch nog altijd door meer dan de helft van alle afgestudeerden belangrijk worden gevonden. Met betrekking tot het belang dat afgestudeerden aan deze werkaspecten toekennen, doen zich geen significante verschillen voor tussen afgestudeerden van deeltijdopleidingen en afgestudeerden van voltijdopleidingen.

Bij de aspecten werkzekerheid, beloning, verantwoordelijkheid, creativiteit, uitdaging, maatschappelijk nut en het combineren van werk-privé wijken sommige faculteiten aanzienlijk (tenminste 10\%-punten) af van het gemiddelde voor voltijdopleidingen. Zo vinden afgestudeerden van de FdCW minder vaak dan gemiddeld dat werkzekerheid, een hoog loon, verantwoordelijkheid dragen en uitdaging van belang zijn in het werk. Daarentegen vinden zij vaker dan gemiddeld dat creativiteit en het combineren van werk met privéleven belangrijke aspecten van werk zijn. Afgestudeerden van de FdEWB zijn relatief materialistisch georiënteerd: van alle afgestudeerden vinden zij een hoog loon het belangrijkst en het maatschappelijk nut van het werk het minst belangrijk. Het maatschappelijk nut van het werk is daartegen van meer dan gemiddeld belang voor afgestudeerden geneeskunde. Voor laatstgenoemden is daarnaast de combinatie werk-privéleven vaker dan gemiddeld van belang.

Aan de afgestudeerden is tevens gevraagd of zij bovengenoemde aspecten voldoende kunnen realiseren in hun huidige werksituatie. Zij konden bij elk aspect aangeven of zij het desbetreffende aspect 'in geringe mate' dan wel 'in sterke mate' kunnen realiseren. Tenminste driekwart van de betaald-werkende afgestudeerden vindt dat zij de aspecten zelfstandigheid (88\%), omgaan met collega's (82\%), afwisseling $(81 \%)$, verantwoordelijkheid $(79 \%)$ en uitdaging $(76 \%)$ in sterke mate in hun huidige werksituatie kunnen realiseren. Wat moeilijker ligt het als het gaat om erkenning door anderen $(70 \%)$, werkzekerheid $(68 \%)$, maatschappelijk nut $(68 \%)$, ontwikkeling van expertise $(66 \%)$, creativiteit $(65 \%)$ en het combineren van werk en privéleven $(61 \%)$. Minder dan de helft $(45 \%)$ van de betaald-werkenden schat in dat zij in hun huidige werksituatie een hoog inkomen kunnen realiseren.

Aan de afgestudeerden is tot slot gevraagd hoe belangrijk het hebben van een betaalde baan voor hen in de toekomst is. Welnu, bijna alle (93\%) afgestudeerden vinden het belangrijk of zeer belangrijk om in de toekomst een betaalde baan te hebben. Wellicht vanwege hun jongere leeftijd zijn afgestudeerden van voltijdopleidingen nog vaker deze mening toegedaan dan afgestudeerden van deeltijdopleidingen, namelijk $94 \%$ versus $86 \%$. Afgestudeerden van de FdEWB (96\%) en FdG (eveneens $96 \%$ ) vinden het vaakst dat het hebben van een betaalde baan in de toekomst belangrijk is, gevolgd door afgestudeerden van de FdGW (93\%) en FdR 
(eveneens 93\%). Afgestudeerden van de FdCW zijn met $79 \%$ het minst vaak deze mening toegedaan.

Tabel 2.14

Belang van werkaspecten in het algemeen (\% belangrijk/zeer belangrijk), meting 1998

\begin{tabular}{|c|c|c|c|c|c|c|}
\hline & $\begin{array}{l}\text { Zelfstandig- } \\
\text { heid }\end{array}$ & $\begin{array}{l}\text { vaste } \\
\text { baan }\end{array}$ & afwisseling & $\begin{array}{l}\text { hoog } \\
\text { inkomen }\end{array}$ & $\begin{array}{l}\text { verantwoor- } \\
\text { delijkheid }\end{array}$ & creativiteit \\
\hline $\begin{array}{l}\text { UM totaal } \\
\text { UM deeltijd } \\
\text { UM voltijd }\end{array}$ & $\begin{array}{l}93 \% \\
96 \% \\
92 \%\end{array}$ & $\begin{array}{l}75 \% \\
80 \% \\
75 \%\end{array}$ & $\begin{array}{l}96 \% \\
93 \% \\
97 \%\end{array}$ & $\begin{array}{l}58 \% \\
73 \% \\
57 \%\end{array}$ & $\begin{array}{l}87 \% \\
95 \% \\
86 \%\end{array}$ & $\begin{array}{l}83 \% \\
82 \% \\
83 \%\end{array}$ \\
\hline \multirow[t]{2}{*}{$\begin{array}{l}\text { FdCW } \\
\text { FdEWB } \\
\text { FdG } \\
\text { FdGW } \\
\text { FdR }\end{array}$} & $\begin{array}{l}90 \% \\
89 \% \\
93 \% \\
94 \% \\
95 \%\end{array}$ & $\begin{array}{l}58 \% \\
77 \% \\
72 \% \\
73 \% \\
79 \%\end{array}$ & $\begin{array}{l}90 \% \\
97 \% \\
98 \% \\
96 \% \\
97 \%\end{array}$ & $\begin{array}{l}21 \% \\
68 \% \\
50 \% \\
51 \% \\
62 \%\end{array}$ & $\begin{array}{l}63 \% \\
83 \% \\
91 \% \\
89 \% \\
85 \%\end{array}$ & $\begin{array}{l}95 \% \\
85 \% \\
83 \% \\
80 \% \\
82 \%\end{array}$ \\
\hline & Uitdaging & $\begin{array}{l}\text { maatschap- } \\
\text { pelijk nut }\end{array}$ & $\begin{array}{l}\text { omgang met } \\
\text { collega's }\end{array}$ & $\begin{array}{l}\text { combineren } \\
\text { werk/privé }\end{array}$ & $\begin{array}{l}\text { ontwikkeling } \\
\text { expertise }\end{array}$ & $\begin{array}{c}\text { erkenning } \\
\text { door anderen }\end{array}$ \\
\hline $\begin{array}{l}\text { UM totaal } \\
\text { UM deeltijd } \\
\text { UM voltijd }\end{array}$ & $\begin{array}{l}93 \% \\
93 \% \\
93 \%\end{array}$ & $\begin{array}{l}72 \% \\
79 \% \\
71 \%\end{array}$ & $\begin{array}{l}90 \% \\
89 \% \\
90 \%\end{array}$ & $\begin{array}{l}74 \% \\
82 \% \\
73 \%\end{array}$ & $\begin{array}{l}85 \% \\
86 \% \\
85 \%\end{array}$ & $\begin{array}{l}78 \% \\
82 \% \\
77 \%\end{array}$ \\
\hline $\begin{array}{l}\text { FdCW } \\
\text { FdEWB } \\
\text { FdG } \\
\text { FdGW } \\
\text { FdR }\end{array}$ & $\begin{array}{l}79 \% \\
94 \% \\
91 \% \\
96 \% \\
94 \%\end{array}$ & $\begin{array}{l}79 \% \\
45 \% \\
90 \% \\
85 \% \\
72 \%\end{array}$ & $\begin{array}{l}84 \% \\
89 \% \\
94 \% \\
93 \% \\
87 \%\end{array}$ & $\begin{array}{l}84 \% \\
68 \% \\
87 \% \\
71 \% \\
68 \%\end{array}$ & $\begin{array}{l}84 \% \\
88 \% \\
84 \% \\
88 \% \\
77 \%\end{array}$ & $\begin{array}{l}74 \% \\
83 \% \\
70 \% \\
79 \% \\
73 \%\end{array}$ \\
\hline
\end{tabular}

Tevredenheid over het werk nader beschouwd

Met behulp van een logistische regressieschatting is nagegaan welke persoonskenmerken (geslacht, leeftijd), opleidingskenmerken (voltijd- versus deeltijdvariant van de opleiding, opleidingsrichting) en kenmerken van het werk (loon, aansluiting naar niveau en richting van de opleiding, zekerheid van de baan) van invloed zijn op de algemene tevredenheid over het gevonden werk. De analyseresultaten staan vermeld in tabel 2.15.

De algemene tevredenheid over het gevonden werk hangt samen met de gevolgde opleidingsrichting en enkele kenmerken van het gevonden werk. Uit de regressieanalyse komt naar voren dat afgestudeerden van de FdGW en FdR minder tevreden zijn met hun werk dan afgestudeerden van de FdEWB (de referentiecategorie), zelfs als wordt gecorrigeerd voor de in de schatting opgenomen persoonskenmerken en baankenmerken. De tevredenheid met het werk hangt verder samen met de aansluiting opleiding-werk naar niveau en richting, gevolgd door de zekerheid van het werk. Afgestudeerden met werk dat aansluit bij het niveau en de richting van hun opleiding zijn meer tevreden over hun werk dan afgestudeerden met werk dat niet aansluit bij hun opleiding, en afgestudeerden met een vaste aanstelling zijn meer tevreden dan afgestudeerden met een tijdelijke aanstelling. De overige in de 
schatting opgenomen verklarende variabelen, namelijk geslacht, leeftijd, voltijdversus deeltijdopleiding alsmede de hoogte van het bruto uurloon blijken geen significant effect te hebben op het al dan niet tevreden zijn over het werk.

Tabel 2.15

Logistische regressieschatting van de tevredenheid met het werk, meting 1998

\begin{tabular}{|c|c|c|}
\hline & B & SE \\
\hline $\begin{array}{l}\text { Persoonskenmerken } \\
\text { Geslacht (man) } \\
\text { Geboortejaar }\end{array}$ & $\begin{array}{r}-0,13 \\
0,01\end{array}$ & $\begin{array}{l}0,24 \\
0,03\end{array}$ \\
\hline $\begin{array}{l}\text { Opleidingskenmerken } \\
\text { Deeltijdopleiding } \\
\text { Opleidingsrichting: } \\
\text { - cultuurwetenschappen } \\
\text { - economie (referentie) } \\
\text { - geneeskunde } \\
\text { - gezondheidswetenschappen }{ }^{\star \star} \\
\text { - rechtsgeleerdheid }\end{array}$ & $\begin{array}{l}-0,16 \\
-0,58 \\
-0,20 \\
-0,86 \\
-0,89\end{array}$ & $\begin{array}{l}0,45 \\
0,33 \\
0,34\end{array}$ \\
\hline $\begin{array}{l}\text { Baankenmerken } \\
\text { Bruto uurloon } \\
\text { Baan op WO-niveau**} \\
\text { Baan in eigen richting } \\
\text { Vaste aanstelling }\end{array}$ & $\begin{array}{r}-0,00 \\
0,97 \\
0,59 \\
0,59\end{array}$ & $\begin{array}{l}0,01 \\
0,25 \\
0,25 \\
0,28\end{array}$ \\
\hline Constante & $-0,06$ & 2,09 \\
\hline
\end{tabular}

** Effect significant op $1 \%$-niveau.

\subsection{Oordeel over de opleiding}

In deze paragraaf worden eerst de gemiddelde 'rapportcijfers' gepresenteerd die door de afgestudeerden aan een zevental aspecten van hun opleiding zijn toegekend, alsmede hun oordeel over de moeilijkheidsgraad en de mate van specialisatie van hun opleiding. Ook wordt ingegaan op de vraag of zij, achteraf bezien, opnieuw dezelfde opleiding aan de UM zouden kiezen.

Aan alle afgestudeerden, dus ook degenen die niet betaald-werken, is gevraagd om een 'rapportcijfer' (een afgerond cijfer, variërend van 1 tot 10) te geven aan elk van de zeven volgende opleidingsaspecten: de samenhang tussen de vakken, de keuzemogelijkheden in de studie, de studiebegeleiding, de kwaliteit van de docenten, de voorbereiding op de beroepspraktijk, de voorlichting over de arbeidsmarktsituatie en de opleiding als geheel. De vraag om een rapportcijfer te geven aan 'de opleiding als geheel' is voor het eerst opgenomen in meting 1998.

Tabel 2.16 laat zien dat de coherentie van het vakkenpakket, de keuzemogelijkheden in de studie, de kwaliteit van het docentencorps en de opleiding als geheel 


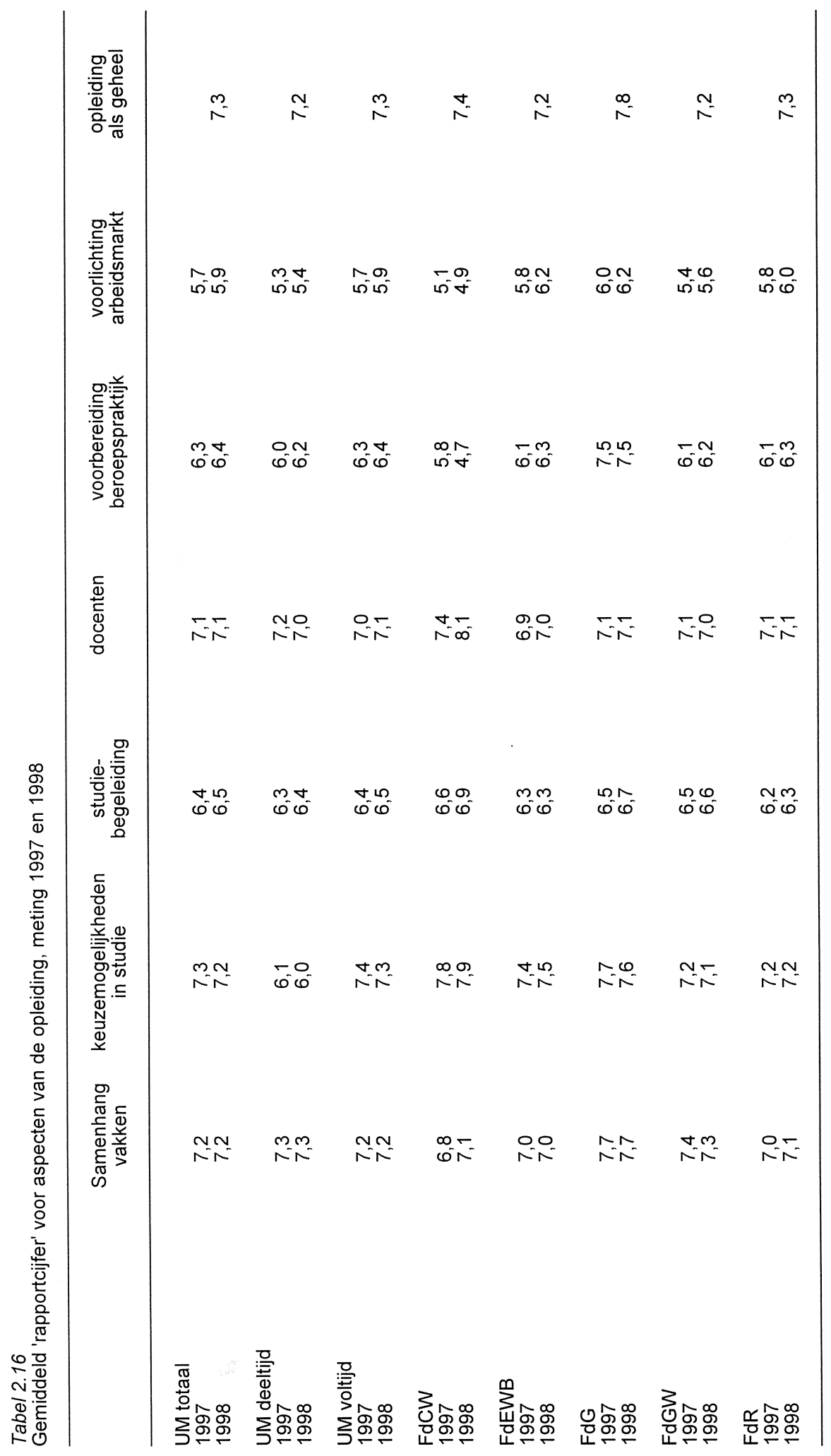


met een gemiddeld rapportcijfer van 7 het beste worden beoordeeld, gevolgd door de studiebegeleiding en de voorbereiding op de beroepspraktijk, die in de ogen van de afgestudeerden voldoende scoren. Het enige opleidingsaspect dat naar de mening van de afgestudeerden net niet voldoende scoort, is de voorlichting over de arbeidsmarkt. De beoordeling van bovengenoemde opleidingsaspecten lijkt vrij stabiel in de tijd, gezien de geringe verschillen tussen beide metingen. Afgestudeerden van deeltijdopleidingen en afgestudeerden van voltijdopleidingen verschillen significant in hun beoordeling van de keuzemogelijkheden in de studie. Afgestudeerden van voltijdopleidingen zijn hierover meer tevreden.

Van alle afgestudeerden van voltijdopleidingen zijn afgestudeerden cultuurwetenschappen het meest tevreden over de kwaliteit van het docentencorps, de keuzemogelijkheden in de studie en de studiebegeleiding. De FdG scoort het hoogst als het gaat om de coherentie van het vakkenpakket, de voorbereiding op de beroepspraktijk en - samen met de FdEWB - de voorlichting over de mogelijkheden op de arbeidsmarkt. Afgestudeerden van de FdG zijn ook het meest positief in hun beoordeling van de opleiding als geheel. Tot slot valt op dat de waardering van afgestudeerden van de FdEWB voor de voorlichting over de arbeidsmarkt ten opzichte van de vorige meting met bijna een half punt is toegenomen.

Moeilijkheidsgraad van de opleiding

Tabel 2.17 laat zien dat de zwaarte van de opleiding volgens de meeste afgestudeerden niet hoeft te worden bijgesteld. Dit laat onverlet dat nog altijd ruim een kwart van de afgestudeerden vindt dat de opleiding best wat zwaarder had mogen zijn, terwijl er nauwelijks afgestudeerden zijn die vinden dat de opleiding minder zwaar zou moeten zijn. In dit verband dient er op te worden gewezen dat de onderzoekspopulatie uitsluitend bestaat uit degenen die de opleiding met goed gevolg hebben afgesloten. Degenen die de opleiding voortijdig hebben verlaten, denken wellicht anders over de zwaarte van de opleiding.

Afgestudeerden van voltijdopleidingen en afgestudeerden van deeltijdopleidingen verschillen niet significant in hun oordeel over de zwaarte van de opleiding. Van alle afgestudeerden zijn juristen het vaakst van mening dat de opleiding zwaarder had mogen zijn. Van de afgestudeerden cultuurwetenschappen was niemand deze mening toegedaan.

Bij deeltijdopleidingen komt naar voren dat het aandeel van afgestudeerden die vinden dat de opleiding best wat zwaarder had mogen zijn ten opzichte van de vorige meting is toegenomen. Daartegen kan bij voltijdopleidingen worden geconstateerd dat het aandeel van afgestudeerden die vinden dat de opleiding best wat zwaarder had mogen zijn juist is afgenomen. Met name bij de FdEWB, FdGW en $\mathrm{FdR}$ is het aandeel van afgestudeerden die de opleiding te gemakkelijk vinden ten opzichte van de vorige meting afgenomen. 
Tabel 2.17

Oordeel over de moeilijkheidsgraad van de opleiding, meting 1997 en 1998

\begin{tabular}{|c|c|c|c|}
\hline & niet hoog genoeg & $\begin{array}{l}\text { heidsgraad van } \\
\text { precies goed }\end{array}$ & te hoog \\
\hline $\begin{array}{l}\text { UM totaal } \\
1997 \\
1998\end{array}$ & $\begin{array}{l}35 \% \\
29 \%\end{array}$ & $\begin{array}{l}64 \% \\
70 \%\end{array}$ & $\begin{array}{l}0 \% \\
1 \%\end{array}$ \\
\hline $\begin{array}{l}\text { UM deeltijd } \\
1997 \\
1998\end{array}$ & $\begin{array}{l}19 \% \\
26 \%\end{array}$ & $\begin{array}{l}81 \% \\
74 \%\end{array}$ & $\begin{array}{l}0 \% \\
0 \%\end{array}$ \\
\hline $\begin{array}{l}\text { UM voltijd } \\
1997 \\
1998\end{array}$ & $\begin{array}{l}37 \% \\
29 \%\end{array}$ & $\begin{array}{l}63 \% \\
70 \%\end{array}$ & $\begin{array}{l}0 \% \\
1 \%\end{array}$ \\
\hline $\begin{array}{l}\text { FdCW } \\
1997 \\
1998\end{array}$ & $\begin{array}{r}11 \% \\
0 \%\end{array}$ & $\begin{array}{l}90 \% \\
90 \%\end{array}$ & $\begin{array}{r}0 \% \\
10 \%\end{array}$ \\
\hline $\begin{array}{l}\text { FdEWB } \\
1997 \\
1998\end{array}$ & $\begin{array}{l}32 \% \\
23 \%\end{array}$ & $\begin{array}{l}67 \% \\
77 \%\end{array}$ & $\begin{array}{l}1 \% \\
1 \%\end{array}$ \\
\hline $\begin{array}{l}\text { FdG } \\
1997 \\
1998\end{array}$ & $\begin{array}{l}32 \% \\
30 \%\end{array}$ & $\begin{array}{l}69 \% \\
70 \%\end{array}$ & $\begin{array}{l}0 \% \\
0 \%\end{array}$ \\
\hline $\begin{array}{l}\text { FdGW } \\
1997 \\
1998\end{array}$ & $\begin{array}{l}41 \% \\
33 \%\end{array}$ & $\begin{array}{l}59 \% \\
67 \%\end{array}$ & $\begin{array}{l}0 \% \\
0 \%\end{array}$ \\
\hline $\begin{array}{l}\text { FdR } \\
1997 \\
1998\end{array}$ & $\begin{array}{l}44 \% \\
37 \%\end{array}$ & $\begin{array}{l}55 \% \\
63 \%\end{array}$ & $\begin{array}{l}1 \% \\
0 \%\end{array}$ \\
\hline
\end{tabular}

Specialisatiegraad van de opleiding

Evenmin als de zwaarte van de opleiding hoeft ook de mate waarin de opleiding is gespecialiseerd volgens de meeste afgestudeerden niet te worden bijgesteld. Dit laat onverlet dat een op de vijf afgestudeerden vindt dat hij te algemeen is opgeleid, terwijl 'slechts' een op twintig vindt dat hij te specialistisch is opgeleid (tabel 2.18). Evenmin als afgestudeerden van voltijdopleidingen en afgestudeerden van deeltijdopleidingen significant verschillen in hun oordeel over de zwaarte van de opleiding, verschillen zij in hun oordeel over de specialisatiegraad van de opleiding.

Van alle afgestudeerden vinden cultuurwetenschappers en gezondheidswetenschappers het vaakst dat hun opleiding te algemeen is. Basisartsen zijn het minst vaak deze mening toegedaan.

Bij deeltijdopleidingen en de FdR is het aandeel van afgestudeerden die de opleiding te algemeen vinden ten opzichte van de vorige meting licht gedaald. Bij de FdG en FdGW valt daartegen een kleine toename waar te nemen van afgestudeer- 
den die vinden dat hun opleiding onvoldoende is gespecialiseerd. De eerste lichting afgestudeerden van de FdCW vond nog relatief vaak dat hun opleiding te specialistisch was. De tweede afstudeerlichting verschilt wat dit betreft niet langer van afgestudeerden van de andere faculteiten.

Tabe/ 2.18

Oordeel over de specialisatiegraad van de opleiding, meting 1997 en 1998

\begin{tabular}{|c|c|c|c|}
\hline & $\begin{array}{l}\text { onvoldoende } \\
\text { gespecialiseerd }\end{array}$ & $\begin{array}{l}\text { De opleiding is: } \\
\text { precies voldoende } \\
\text { gespecialiseerd }\end{array}$ & te specialistisch \\
\hline $\begin{array}{l}\text { UM totaal } \\
1997 \\
1998\end{array}$ & $\begin{array}{l}21 \% \\
21 \%\end{array}$ & $\begin{array}{l}73 \% \\
73 \%\end{array}$ & $\begin{array}{l}6 \% \\
5 \%\end{array}$ \\
\hline $\begin{array}{l}\text { UM deeltijd } \\
1997 \\
1998\end{array}$ & $\begin{array}{l}25 \% \\
16 \%\end{array}$ & $\begin{array}{l}73 \% \\
81 \%\end{array}$ & $\begin{array}{l}2 \% \\
3 \%\end{array}$ \\
\hline $\begin{array}{l}\text { UM voltijd } \\
1997 \\
1998\end{array}$ & $\begin{array}{l}21 \% \\
22 \%\end{array}$ & $\begin{array}{l}73 \% \\
72 \%\end{array}$ & $\begin{array}{l}6 \% \\
6 \%\end{array}$ \\
\hline $\begin{array}{l}\text { FdCW } \\
1997 \\
1998\end{array}$ & $\begin{array}{l}37 \% \\
37 \%\end{array}$ & $\begin{array}{l}47 \% \\
58 \%\end{array}$ & $\begin{array}{r}16 \% \\
5 \%\end{array}$ \\
\hline $\begin{array}{l}\text { FdEWB } \\
1997 \\
1998\end{array}$ & $\begin{array}{l}17 \% \\
17 \%\end{array}$ & $\begin{array}{l}77 \% \\
76 \%\end{array}$ & $\begin{array}{l}6 \% \\
7 \%\end{array}$ \\
\hline $\begin{array}{l}\text { FdG } \\
1997 \\
1998\end{array}$ & $\begin{array}{l}5 \% \\
9 \%\end{array}$ & $\begin{array}{l}92 \% \\
91 \%\end{array}$ & $\begin{array}{l}2 \% \\
0 \%\end{array}$ \\
\hline $\begin{array}{l}\text { FdGW } \\
1997 \\
1998\end{array}$ & $\begin{array}{l}26 \% \\
32 \%\end{array}$ & $\begin{array}{l}66 \% \\
60 \%\end{array}$ & $\begin{array}{l}8 \% \\
8 \%\end{array}$ \\
\hline $\begin{array}{l}\text { FdR } \\
1997 \\
1998\end{array}$ & $\begin{array}{l}28 \% \\
24 \%\end{array}$ & $\begin{array}{l}67 \% \\
72 \%\end{array}$ & $\begin{array}{l}5 \% \\
5 \%\end{array}$ \\
\hline
\end{tabular}

Tevredenheid over de opleiding nader beschouwd

Het rapportcijfer dat afgestudeerden geven voor 'de opleiding als geheel' (zie tabel 2.17) kan worden gezien als een indicatie voor hun algehele tevredenheid over de gevolgde opleiding. Met behulp van een lineaire regressieschatting is voor meting 1998 nagegaan welke opleidingsaspecten hierop van invloed zijn. De analyseresultaten staan vermeld in tabel 2.19 .

De resultaten van de regressie-analyse tonen dat de algehele tevredenheid over de gevolgde opleiding samenhangt met de gevolgde opleidingsrichting en de tevredenheid over bepaalde aspecten van de opleiding. Van alle afgestudeerden blijken basisartsen het meest tevreden te zijn over hun opleiding. Verder blijkt dat de 
tevredenheid over de opleiding vooral afhangt van de tevredenheid over de kwaliteit van de docenten, gevolgd door de tevredenheid over de samenhang tussen de vakken, de keuzemogelijkheden in de studie, de voorbereiding op de beroepspraktijk, de mate van specialisatie van de opleiding en de arbeidsmarktvoorlichting.

De overige in de schatting opgenomen verklarende variabelen, namelijk geslacht, leeftijd, voltijd- versus deeltijdopleiding, tevredenheid over de studiebegeleiding, alsmede het oordeel over de moeilijkheidsgraad van de opleiding blijken geen significant effect te hebben op de overall tevredenheid over de opleiding. Overigens verklaren bovengenoemde variabelen samen $45 \%$ van de variantie in de algehele tevredenheid over de gevolgde opleiding.

Tabe/ 2.19

Lineaire regressieschatting van het rapportcijfer voor 'de opleiding als geheel', meting 1998

\begin{tabular}{|c|c|c|}
\hline & Beta & t-waarde \\
\hline $\begin{array}{l}\text { Persoonskenmerken } \\
\text { Geslacht (man) } \\
\text { Geboortejaar }\end{array}$ & $\begin{array}{r}0,02 \\
-0,03\end{array}$ & $\begin{array}{r}0,45 \\
-0,75\end{array}$ \\
\hline $\begin{array}{l}\text { Opleidingskenmerken } \\
\text { Deeltijdopleiding } \\
\text { Opleidingsrichting: } \\
\text { - cultuurwetenschappen } \\
\text { - economie (referentie) } \\
\text { - geneeskunde } \\
\text { - gezondheidswetenschappen } \\
\text { - rechtsgeleerdheid }\end{array}$ & $\begin{array}{l}0,01 \\
0,01 \\
0,10 \\
0,03 \\
0,06\end{array}$ & $\begin{array}{l}0,21 \\
0,16 \\
2,41 \\
0,72 \\
1,44\end{array}$ \\
\hline $\begin{array}{l}\text { Oordeel over opleidingsaspecten } \\
\text { Moeilijkheidsgraad is precies goed } \\
\text { Specialisatiegraad is precies goed** } \\
\text { Rapportcijfer voor: } \\
\text { - samenhang tussen vakken }{ }^{\star *} \\
\text { - keuzemogelijkheden in studie**} \\
\text { - studiebegeleiding } \\
\text { - kwaliteit van docenten** } \\
\text { - voorbereiding op beroepspraktijk } \\
\text { - voorlichting over arbeidsmarktsituatie* }\end{array}$ & $\begin{array}{l}0,03 \\
0,09 \\
0,18 \\
0,18 \\
0,05 \\
0,29 \\
0,18 \\
0,08\end{array}$ & $\begin{array}{l}0,82 \\
2,61 \\
5,10 \\
5,11 \\
1,28 \\
7,54 \\
3,96 \\
1,98\end{array}$ \\
\hline
\end{tabular}

* Effect significant op 5\%-niveau.

** Effect significant op $1 \%$-niveau.

\section{Studiekeuze achteraf bezien}

Het antwoord op de vraag of de afgestudeerden achteraf bezien opnieuw dezelfde opleiding aan de UM zouden zijn gaan volgen, kan worden beschouwd als een indicatie van hun algemene tevredenheid over de destijds gemaakte studiekeuze. De cijfers in tabel 2.20 tonen dat ruim driekwart (77\%) van de afgestudeerden achteraf tevreden is met de destijds gemaakte studiekeuze: zij zouden opnieuw dezelfde opleiding aan de UM zijn gaan volgen. Zes procent is weliswaar tevreden met de destijds gekozen opleiding maar niet met de UM: zij zouden achteraf bezien 
weliswaar voor dezelfde opleiding, maar dan voor een andere universiteit hebben gekozen. Een op de zes afgestudeerden (16\%) heeft spijt van de destijds gemaakte studiekeuze: zij zouden, achteraf bezien, een andere universitaire opleiding hebben gekozen $(12 \%)$, een niet-universitaire opleiding zijn gaan volgen $(4 \%)$ of niet zijn gaan studeren (1\%). Afgestudeerden van voltijdopleidingen en afgestudeerden van deeltijdopleidingen verschillen niet significant in hun tevredenheid over de destijds gemaakte studiekeuze.

Tabel 2.20

Opleidingskeuze achteraf bezien, meting 1997 en 1998

\begin{tabular}{|c|c|c|c|c|c|}
\hline & $\begin{array}{l}\text { zelfde opleiding } \\
\text { aan UM kiezen }\end{array}$ & $\begin{array}{l}\quad \text { Alumnus zou } \\
\text { zelfde opleiding } \\
\text { maar andere } \\
\text { universiteit kiezen }\end{array}$ & $\begin{array}{l}\text { achteraf bezien: } \\
\text { andere WO- } \\
\text { opleiding } \\
\text { kiezen }\end{array}$ & $\begin{array}{l}\text { opleiding } \\
\text { buiten WO } \\
\text { kiezen }\end{array}$ & $\begin{array}{l}\text { niet zijn } \\
\text { gaan } \\
\text { studeren }\end{array}$ \\
\hline $\begin{array}{l}\text { UM totaal } \\
1997 \\
1998\end{array}$ & $\begin{array}{l}77 \% \\
77 \%\end{array}$ & $\begin{array}{l}7 \% \\
6 \%\end{array}$ & $\begin{array}{l}13 \% \\
12 \%\end{array}$ & $\begin{array}{l}2 \% \\
4 \%\end{array}$ & $\begin{array}{l}0 \% \\
1 \%\end{array}$ \\
\hline $\begin{array}{l}\text { UM deeltijd } \\
1997 \\
1998\end{array}$ & $\begin{array}{l}68 \% \\
68 \%\end{array}$ & $\begin{array}{r}12 \% \\
7 \%\end{array}$ & $\begin{array}{l}18 \% \\
23 \%\end{array}$ & $\begin{array}{l}0 \% \\
2 \%\end{array}$ & $\begin{array}{l}2 \% \\
0 \%\end{array}$ \\
\hline $\begin{array}{l}\text { UM voltijd } \\
1997 \\
1998\end{array}$ & $\begin{array}{l}78 \% \\
78 \%\end{array}$ & $\begin{array}{l}6 \% \\
6 \%\end{array}$ & $\begin{array}{l}13 \% \\
11 \%\end{array}$ & $\begin{array}{l}3 \% \\
4 \%\end{array}$ & $\begin{array}{l}0 \% \\
1 \%\end{array}$ \\
\hline $\begin{array}{l}\text { FdCW } \\
1997 \\
1998\end{array}$ & $\begin{array}{l}74 \% \\
70 \%\end{array}$ & $\begin{array}{l}5 \% \\
0 \%\end{array}$ & $\begin{array}{l}21 \% \% \\
10 \%\end{array}$ & $\begin{array}{r}0 \% \\
20 \%\end{array}$ & $\begin{array}{l}0 \% \\
0 \%\end{array}$ \\
\hline $\begin{array}{l}\text { FdEWB } \\
1997 \\
1998\end{array}$ & $\begin{array}{l}80 \% \\
85 \%\end{array}$ & $\begin{array}{l}7 \% \\
4 \%\end{array}$ & $\begin{array}{r}10 \% \\
6 \%\end{array}$ & $\begin{array}{l}3 \% \\
4 \%\end{array}$ & $\begin{array}{l}1 \% \\
1 \%\end{array}$ \\
\hline $\begin{array}{l}\text { FdG } \\
1997 \\
1998\end{array}$ & $\begin{array}{l}88 \% \\
88 \%\end{array}$ & $\begin{array}{l}8 \% \\
7 \%\end{array}$ & $\begin{array}{l}3 \% \\
2 \%\end{array}$ & $\begin{array}{l}1 \% \\
3 \%\end{array}$ & $\begin{array}{l}0 \% \\
0 \%\end{array}$ \\
\hline $\begin{array}{l}\text { FdGW } \\
1997 \\
1998\end{array}$ & $\begin{array}{l}69 \% \\
69 \%\end{array}$ & $\begin{array}{l}4 \% \\
3 \%\end{array}$ & $\begin{array}{l}23 \% \\
24 \%\end{array}$ & $\begin{array}{l}3 \% \\
3 \%\end{array}$ & $\begin{array}{l}0 \% \\
1 \%\end{array}$ \\
\hline $\begin{array}{l}\text { FdR } \\
1997 \\
1998\end{array}$ & $\begin{array}{l}80 \% \\
74 \%\end{array}$ & $\begin{array}{r}7 \% \\
13 \%\end{array}$ & $\begin{array}{r}10 \% \\
8 \%\end{array}$ & $\begin{array}{l}3 \% \\
3 \%\end{array}$ & $\begin{array}{l}0 \% \\
2 \%\end{array}$ \\
\hline
\end{tabular}

Van alle afgestudeerden van voltijdopleidingen zouden afgestudeerden cultuurwetenschappen, achteraf bezien, het vaakst een niet-universitaire opleiding zijn gaan volgen.

Afgestudeerden van de FdGW zouden achteraf bezien relatief vaak een andere universitaire opleiding kiezen. Dat slechts $3 \%$ van hen opnieuw dezelfde opleiding zou gaan volgen maar niet meer in Maastricht, duidt er op dat gezondheidsweten- 
schappers wel tevreden zijn over de Universiteit Maastricht maar niet over de gekozen opleiding gezondheidswetenschappen.

Afgestudeerden van de FdR hebben relatief het vaakst spijt van het feit dat zij specifiek voor de UM hebben gekozen: $13 \%$ zou opnieuw voor een juridische opleiding maar niet meer voor Maastricht kiezen, terwijl 'slechts' $8 \%$ een niet-juridische opleiding zou hebben gekozen.

Afgestudeerden van de FdG en FdEWB zijn van alle afgestudeerden het vaakst tevreden over de destijds gemaakte studiekeuze.

Uit de vergelijking van de twee metingen komt het volgende beeld naar voren: een toename van de tevredenheid over de keuze voor de UM en tegelijkertijd een daling van de tevredenheid over de gekozen opleiding (afgestudeerden van deeltijdopleidingen), een daling van de tevredenheid over de gekozen opleiding (afgestudeerden van de $\mathrm{FdCW}$ ), een toename van de tevredenheid over de keuze voor de UM (afgestudeerden van de FdEWB) en een daling van de tevredenheid over de keuze voor de UM (afgestudeerden van de FdR). Hieronder wordt een en ander kort toegelicht.

Deeltijders: Bij een gelijkblijvende tevredenheid over de keuze om de opleiding specifiek aan de UM te gaan volgen en een daling van het aandeel van afgestudeerden die opnieuw dezelfde opleiding zouden volgen maar niet meer in Maastricht, is het aandeel van afgestudeerden die achteraf een andere opleiding zouden hebben gekozen gestegen.

FdCW: $\quad$ Bij afgestudeerden van de $\mathrm{FdCW}$ is weliswaar de tevredenheid over de keuze om destijds specifiek voor de UM te kiezen per saldo gelijk gebleven, maar de tevredenheid over de keuze om destijds specifiek voor cultuurwetenschappen te kiezen per saldo gedaald.

FdEWB: $\quad$ Bij afgestudeerden van de FdEWB is de tevredenheid over de keuze om destijds specifiek voor de UM te kiezen toegenomen: het aandeel van afgestudeerden die opnieuw voor economie aan de UM zouden kiezen is gestegen, terwijl het aandeel van afgestudeerden die opnieuw economie zouden gaan studeren maar niet meer in Maastricht is gedaald.

FdR: $\quad$ Bij de FdR valt het omgekeerde waar te nemen: het aandeel van afgestudeerden die opnieuw voor rechtsgeleerdheid aan de UM zouden kiezen is gedaald, terwijl het aandeel van afgestudeerden die opnieuw rechtsgeleerdheid zouden gaan studeren maar niet meer in Maastricht is gestegen.

$\mathrm{Bij}$ de FdG en FdGW is de tevredenheid van de afgestudeerden over de destijds gemaakte studiekeuze tussen beide metingen nauwelijks veranderd. 


\section{Ontwikkeling arbeidsmarktintrede over de afgelopen vijf jaar}

Dit hoofdstuk bevat een beknopte weergave van de ontwikkelingen met betrekking tot de arbeidsmarktintrede van de afstudeerjaargangen 1993-1997. De ontwikkeling van de arbeidsmarktintrede over de afgelopen vijf jaar wordt geschetst aan de hand van de ontwikkeling van de kans op werk (het procentuele aandeel van afgestudeerden die behoren tot de werkloze beroepsbevolking), de zekerheid van het werk (het procentuele aandeel van betaald-werkende afgestudeerden met een vaste aanstelling), de beloning van betaald-werkende afgestudeerden en de aansluiting tussen de gevolgde opleiding en het uitgeoefende werk naar achtereenvolgens niveau en richting.

Vanwege de numeriek kleine eerste lichtingen afgestudeerden van de $\mathrm{FdCW}$ in het onderzoekbestand (meting 1996: 5 respondenten; meting 1997: 19 respondenten; meting 1998: 20 respondenten) worden de resultaten met betrekking tot deze faculteit niet afzonderlijk vermeld. Hetzelfde geldt voor de eerste lichting afgestudeerden kennistechnologie (2 respondenten in meting 1998). De desbetreffende afgestudeerden cultuurwetenschappen en kennistechnologie zijn wel steeds meegerekend in de totaalcijfers voor de UM. De in dit hoofdstuk gepresenteerde facultaire cijfers betreffen zowel voltijd- als deeltijdopleidingen. De hier gepresenteerde cijfers voor de FdGW en FdR kunnen derhalve afwijken van de in het vorige hoofdstuk gepresenteerde cijfers voor deze faculteiten, die alleen betrekking hadden op afgestudeerden van voltijdopleidingen.

Bij de ontwikkeling van de arbeidsmarktintrede dient te worden bedacht dat zich in de loop van de jaren negentig een sterke omslag in de landelijke arbeidsmarktsituatie voor afgestudeerden heeft voorgedaan. In de eerste helft van de jaren negentig werd de groei van het aantal baanopeningen voor nieuwkomers teniet gedaan door de omvangrijke groei van het aantal afgestudeerden. De tweede helft van de jaren negentig wordt gekenmerkt door aan de ene kant een verdere toename van het aantal baanopeningen voor nieuwkomers en aan de andere kant een teruglopende instroom van afgestudeerden op de arbeidsmarkt.

Ontwikkeling van de kans op werk

De eerder geschetste algemene omslag in de landelijke arbeidsmarktsituatie in de loop van de jaren negentig is in de ontwikkeling van de werkloosheid onder afgestudeerden van de UM tot uiting gekomen. Zo is de werkloosheid voor de UM als geheel in de periode $1994 \mathrm{t} / \mathrm{m} 1997$ gestaag gedaald. In het laatste meetjaar bedroeg de werkloosheid, evenals het daaraan voorafgaande jaar, slechts $3 \%$ (tabel 3.1). De daling van de werkloosheid over de afgelopen vijf jaar is het grootst geweest onder afgestudeerden van de FdEWB. De werkloosheid is steeds traditioneel laag geweest onder afgestudeerden van de FdG. 
Tabel 3.1

Ontwikkeling van de werkloosheid, meetjaar 1994-1998

\begin{tabular}{lrrrrr}
\hline & 1994 & 1995 & 1996 & 1997 & 1998 \\
\hline FdEWB & $15 \%$ & $7 \%$ & $5 \%$ & $2 \%$ & $3 \%$ \\
FdG & $3 \%$ & $1 \%$ & $0 \%$ & $1 \%$ & $0 \%$ \\
FdGW & $12 \%$ & $8 \%$ & $8 \%$ & $4 \%$ & $4 \%$ \\
FdR & $8 \%$ & $10 \%$ & $7 \%$ & $2 \%$ & $2 \%$ \\
Totaal UM & $10 \%$ & $7 \%$ & $6 \%$ & $3 \%$ & $3 \%$ \\
\hline
\end{tabular}

Ontwikkeling van de werkzekerheid

Tabel 3.2 toont dat de zekerheid van het werk in 1995 aanzienlijk is toegenomen, waarna een stabilisatie heeft plaatsgevonden. Alleen bij de FdEWB lijkt de zeer krappe arbeidsmarkt van de afgelopen jaren te hebben geleid tot een gestaag en fors groeiend aandeel van afgestudeerden met een vaste baan. Het lijkt alsof de toenemende krapte op de arbeidsmarkt ertoe leidt dat werkgevers vaker een vaste aanstelling moeten bieden om aan voldoende economisch geschoold personeel te komen. De relatief lage werkzekerheid van afgestudeerden van de FdG houdt verband met de doorstroom van basisartsen naar per definitie tijdelijke opleidingsplaatsen.

Tabel 3.2

Ontwikkeling van de werkzekerheid, meetjaar 1994-1998

\begin{tabular}{lrrrrr}
\hline & 1994 & 1995 & 1996 & 1997 & 1998 \\
\hline FdEWB & $49 \%$ & $58 \%$ & $56 \%$ & $66 \%$ & $70 \%$ \\
FdG & $9 \%$ & $21 \%$ & $17 \%$ & $17 \%$ & $20 \%$ \\
FdGW & $43 \%$ & $48 \%$ & $49 \%$ & $45 \%$ & $49 \%$ \\
FdR & $47 \%$ & $51 \%$ & $48 \%$ & $50 \%$ & $49 \%$ \\
Totaal UM & $40 \%$ & $48 \%$ & $47 \%$ & $49 \%$ & $49 \%$ \\
\hline
\end{tabular}

Ontwikkeling van de lonen

De huidige krapte op de arbeidsmarkt voor afgestudeerden blijkt overduidelijk uit de ontwikkeling van het loon. Tabel 3.3 toont dat de lonen ten opzichte van het vorige meetjaar fors zijn toegenomen. Zo nam het totale bruto maandloon voor de UM als geheel met $6 \%$ toe. Per uur gerekend, bedroeg de toename van het bruto loon gemiddeld zelfs $11 \%$. Een deel van de loonstijging wordt overigens veroorzaakt door de toegenomen arbeidsduurverkorting. Van alle afgestudeerden was de toename van het loon ten opzichte van het vorige meetjaar het grootst bij afgestudeerden gezondheidswetenschappen. 
Tabel 3.3

Ontwikkeling van de lonen, meetjaar 1994-1998

\begin{tabular}{llllll}
\hline 1994 & 1995 & 1996 & 1997 & 1998 \\
\hline
\end{tabular}

Gemiddeld bruto maandloon (incl. nevenfuncties), in guldens

$\begin{array}{llllll}\text { FdEWB } & f 3.830 & f 3.880 & f 3.710 & f 3.830 & f 4.060 \\ \text { FdG } & f 4.770 & f 4.510 & f 4.620 & f 4.210 & f 4.470 \\ \text { FdGW } & f 3.900 & f 3.480 & f 3.530 & f 3.590 & f 4.020 \\ \text { FdR } & f 3.790 & f 3.720 & f 3.580 & f 3.610 & f 3.570 \\ \text { Totaal UM } & f 4.000 & f 3.770 & f 3.710 & f 3.750 & f 3.980\end{array}$

Gemiddeld bruto uurloon (excl. nevenfuncties), in guldens

$\begin{array}{llllll}\text { FdEWB } & f 23,10 & f 22,10 & f 21,70 & f 22,50 & f 24,20 \\ \text { FdG } & f 27,40 & f 24,10 & f 24,40 & f 23,80 & f 26,20 \\ \text { FdGW } & f 24,40 & f 23,10 & f 23,40 & f 23,70 & f 28,10 \\ \text { FdR } & f 23,20 & f 22,10 & f 20,50 & f 22,00 & f 21,90 \\ \text { Totaal UM } & f 24,30 & f 22,80 & f 22,40 & f 22,80 & f 25,30\end{array}$

De in de tabel opgenomen maand- en uurlonen zijn gecorrigeerd op basis van de ontwikkeling van het Prijsindexcijfer voor Gezinsconsumptie (op basis van 1994 consumentenprijzen). De maandlonen zijn afgerond op 10 gulden; de uurlonen op 10 cent.

Ontwikkeling van de aansluiting naar opleidingsniveau

Eerder is aangegeven dat zich in de loop van de jaren negentig een sterke omslag in de landelijke arbeidsmarktsituatie heeft voltrokken, die tot uiting is gekomen in de ontwikkeling van de kans op werk en de lonen van afgestudeerden. Ook de ontwikkeling van de aansluiting opleiding-werk naar niveau heeft in de jaren negentig een kentering te zien gegeven, zij het pas laat in de jaren negentig. Tabel 3.4 laat zien

Tabel 3.4

Ontwikkeling van de aansluiting van het werk naar opleidingsniveau, meetjaar 1994-1998

\begin{tabular}{lrrrrr}
\hline & 1994 & 1995 & 1996 & 1997 & 1998 \\
\hline FdEWB & $60 \%$ & $55 \%$ & $49 \%$ & $49 \%$ & $58 \%$ \\
FdG & $99 \%$ & $99 \%$ & $100 \%$ & $100 \%$ & $100 \%$ \\
FdGW & $52 \%$ & $36 \%$ & $39 \%$ & $48 \%$ & $49 \%$ \\
FdR & $78 \%$ & $72 \%$ & $67 \%$ & $70 \%$ & $69 \%$ \\
Totaal UM & $65 \%$ & $55 \%$ & $54 \%$ & $60 \%$ & $63 \%$ \\
\hline
\end{tabular}

dat voor de UM als geheel het aandeel van afgestudeerden met werk dat past bij hun opleidingsniveau tot 1996 jaarlijks daalde. Na 1996 neemt het aandeel van niveau-passend werk weer toe. Vooral onder afgestudeerden van de FdEWB is het aandeel van niveau-passend werk ten opzichte van de vorige meting flink toegenomen. 


\section{Ontwikkeling van de aans/uiting naar opleidingsrichting}

De aansluiting naar richting tussen de gevolgde UM-opleiding en het uitgeoefende werk laat over de afgelopen vijf jaar een fluctuerend verloop zien (tabel 3.5). Met andere woorden, het aandeel van afgestudeerden die buiten de eigen vakrichting gaan werken schommelt jaarlijks.

Tabel 3.5

Ontwikkeling van de aansluiting van het werk naar opleidingsrichting, meetjaar 1994-1998

\begin{tabular}{lccccc}
\hline & 1994 & 1995 & 1996 & 1997 & 1998 \\
\hline FdEWB & $75 \%$ & $74 \%$ & $69 \%$ & $73 \%$ & $73 \%$ \\
FdG & $87 \%$ & $89 \%$ & $98 \%$ & $97 \%$ & $100 \%$ \\
FdGW & $77 \%$ & $73 \%$ & $79 \%$ & $81 \%$ & $75 \%$ \\
FdR & $80 \%$ & $75 \%$ & $69 \%$ & $79 \%$ & $72 \%$ \\
Totaal UM & $79 \%$ & $76 \%$ & $76 \%$ & $80 \%$ & $77 \%$ \\
\hline
\end{tabular}

Resumerend laat de ontwikkeling van de arbeidsmarktintrede van afgestudeerden van de UM zien dat:

- de werkloosheid de afgelopen vijf jaar sterk is gedaald;

- de werkzekerheid zich, na de sterke toename in 1995, heeft gestabiliseerd;

- de lonen het afgelopen jaar fors zijn gestegen;

- het aandeel van niveau-passend werk de laatste twee jaar flink stijgt;

- het aandeel van richting-passend werk schommelt rond $78 \%$.

Kortom, de economische hoogconjunctuur van de laatste jaren heeft er niet alleen toe bijgedragen dat het vinden van betaald werk voor pas afgestudeerden van de UM nauwelijks nog een probleem vormt, maar ook dat het gevonden werk steeds vaker aansluit bij hun opleidingsniveau en steeds beter wordt beloond. 


\section{Arbeidsmarktintrede cohort 1997: vergelijking UM- landelijk}

Zoals eerder reeds is vermeld, verricht het ROA vanaf 1990 jaarlijks onderzoek naar de arbeidsmarktintrede van afgestudeerden van de UM. In de loop der jaren is dit onderzoek verbreed naar andere economische faculteiten en een technische universiteit. Aan de meest recente meting, die eind 1998/begin 1999 heeft plaatsgevonden onder afgestudeerden van studiejaar 1996/1997 (cohort 1997), hebben voor de eerste keer afgestudeerden van alle Nederlandse universiteiten deelgenomen. Hierdoor is het mogelijk om de resultaten met betrekking tot de FdEWB, FdG en FdR af te zetten tegen de desbetreffende landelijke cijfers. Omwille van de vergelijkbaarheid zijn deze landelijke cijfers alléén gebaseerd op dié opleidingen die binnen de desbetreffende faculteit van de UM worden aangeboden. In dit hoofdstuk worden de drie bovengenoemde faculteiten van de UM vergeleken met het landelijk gemiddelde met betrekking tot achtereenvolgens de intrede van de afgestudeerden op de arbeidsmarkt en het oordeel van de afgestudeerden over de gevolgde opleiding.

\subsection{Vergelijking van de kans op werk en kwaliteit van het werk}

Eventuele verschillen in arbeidsmarktintrede tussen afgestudeerden van de UM en landelijk worden geschetst aan de hand van de kans op werk (het procentuele aandeel van afgestudeerden die behoren tot de werkloze beroepsbevolking), de zekerheid van het werk (het procentuele aandeel van betaald-werkende afgestudeerden met een vaste aanstelling), de beloning van betaald-werkende afgestudeerden en de aansluiting tussen de gevolgde opleiding en het uitgeoefende werk naar achtereenvolgens niveau en richting. Hierbij dient te worden opgemerkt dat het bruto verschillen betreft, waarbij niet is gecorrigeerd voor eventuele verschillen in bijvoorbeeld regionale werkgelegenheidssituatie of kwaliteit van de instroom.

Kans op werk en werkzekerheid

De werkloosheid onder de aan de UM afgestudeerde economen, basisartsen en juristen verschilt niet significant van de werkloosheid onder hun vakgenoten die elders zijn afgestudeerd (tabel 4.1). Ook wat de zekerheid van het werk betreft, verschillen afgestudeerden van de UM niet significant van afgestudeerden van andere universiteiten.

\section{Beloning}

Hoewel afgestudeerden van de FdR door de bank genomen minder verdienen dan juristen die aan andere universiteiten zijn afgestudeerd (tabel 4.2), zijn de verschillen in maand- en uurloon niet significant op 1\%-niveau. Ook de lonen van aan de UM afgestudeerde basisartsen en economen verschillen niet significant van de lonen 
van hun vakgenoten die elders hebben gestudeerd, zowel in totaal per maand als per uur gerekend.

Tabel 4.1

Werkloosheid en werkzekerheid, UM-landelijk (meetjaar 1998)

\begin{tabular}{lllll}
\hline & \multicolumn{2}{c}{ Werkloosheid } & \multicolumn{2}{c}{ werkzekerheid } \\
& UM & landelijk & UM & \\
& & & $70 \%$ & $71 \%$ \\
FdEWB & $3,3 \%$ & $1,1 \%$ & $20 \%$ & $21 \%$ \\
FdG & $0,0 \%$ & $0,6 \%$ & $49 \%$ & $57 \%$ \\
FdR & $1,8 \%$ & $2,5 \%$ & & \\
\hline
\end{tabular}

Tabel 4.2

Gemiddeld bruto loon in guldens, UM-landelijk (meetjaar 1998)

\begin{tabular}{|c|c|c|}
\hline & $\begin{array}{l}\text { Bruto maandloon } \\
\text { (incl. nevenfuncties) } \\
\text { UM landelijk }\end{array}$ & $\begin{array}{l}\text { bruto uurloon } \\
\text { (excl. nevenfuncties) } \\
\text { UM landelijk }\end{array}$ \\
\hline $\begin{array}{l}\text { FdEWB } \\
\text { FdG } \\
\text { FdR }\end{array}$ & $\begin{array}{l}f 4.660 \\
f 5.000 \\
f 5.020\end{array}$ & $\begin{array}{l}f 27,80 \\
f 29,60 \\
f 27,40\end{array}$ \\
\hline
\end{tabular}

Aansluiting opleiding-werk

Uit de vergelijking in tabel 4.3 komt naar voren dat afgestudeerden van de UM niet significant afwijken van afgestudeerden van andere universiteiten wat de aansluiting van het werk naar opleidingsniveau en -richting betreft.

Tabel 4.3

Aansluiting opleiding-werk, UM-landelijk (meetjaar 1998)

\begin{tabular}{lcccc}
\hline & \multicolumn{2}{c}{ Aansluiting naar: } & \multicolumn{2}{c}{ opleidingsrichting } \\
& opleidingsniveau \\
& UM & landelijk & UM & landelijk \\
& & & & \\
& & $58 \%$ & $73 \%$ & $77 \%$ \\
FdEWB & $58 \%$ & $99 \%$ & $100 \%$ & $100 \%$ \\
FdG & $100 \%$ & $72 \%$ & $72 \%$ & $78 \%$ \\
FdR & $69 \%$ & & & \\
\hline
\end{tabular}

\subsection{Vergelijking van het oordeel over de opleiding}

Eventuele verschillen in het oordeel over de gevolgde opleiding tussen afgestudeerden van de UM en landelijk worden geschetst aan de hand van achtereenvolgens: 
- de in de opleiding gewenste aandacht voor kennisaspecten, vaardigheden en werkhoudingen;

- de gemiddelde 'rapportcijfers' die de door de afgestudeerden aan een zevental aspecten van hun opleiding zijn toegekend;

- het oordeel van afgestudeerden over de moeilijkheidsgraad en mate van specialisatie van hun opleiding;

- de vraag of de afgestudeerden, achteraf bezien, opnieuw dezelfde opleiding aan dezelfde universiteit zouden kiezen.

Gewenste aandacht in de opleiding voor competenties

Aan de betaald-werkende afgestudeerden is een lijst met aspecten voorgelegd die verwijzen naar beroepseisen ten aanzien van kennis en technieken, vaardigheden en attitudes. Zij zijn gevraagd om bij elk aspect aan te geven of het desbetreffende aspect minder, evenveel of meer aandacht zou moeten krijgen dan tijdens hun opleiding het geval is geweest. In tabel 4.4 staat per aspect vermeld hoeveel procent van de betaal-werkende afgestudeerden te kennen heeft gegeven dat hun opleiding aan het betreffende aspect meer aandacht had moeten schenken.

De tabel laat zien dat afgestudeerden van de UM significant afwijken van het landelijk gemiddelde als het gaat om de gewenste aandacht voor drie kennisaspecten, namelijk vakkennis, vakspecifieke methoden en technieken (M\&T) en inzicht in informatie- en communicatietechnologie (ICT), acht vaardigheidsaspecten, namelijk het toepassen van (theoretische) kennis en technieken in de praktijk, analytische en diagnostische (onderzoeks)vaardigheden, kwantitatieve (onderzoeks)vaardigheden, schriftelijk en mondeling presenteren, het oplossen van problemen, contactuele vaardigheden en het werken in teamverband, alsmede drie houdingsaspecten, namelijk zelfstandigheid, initiatief/creativiteit en loyaliteit/integriteit/omgaan met belangentegenstellingen. Op al deze aspecten, behoudens drie kennisaspecten (vakkennis, vakspecifieke M\&T en inzicht in ICT), scoren bepaalde faculteiten van de UM beter dan het landelijk gemiddelde. Hierna wordt kort op deze verschillen ingegaan.

FdEWB: Vergeleken met hun elders afgestudeerde vakgenoten vinden afgestudeerden van de FdEWB vaker dat hun opleiding tekortschiet in de aandacht voor vakkennis en vakspecifieke M\&T. Echter als het gaat om communicatieve vaardigheden (mondelinge en schriftelijke vaardigheden) en sociale vaardigheden (contactuele vaardigheden en teamwork) zijn afgestudeerden van de FdEWB vaker tevreden over hun opleiding dan elders afgestudeerde economen.

FdG: $\quad$ Afgestudeerden van de FdG zijn vaker tevreden dan elders afgestudeerde basisartsen ten aanzien van de hoeveelheid aandacht die hun opleiding heeft besteed aan vakspecifieke M\&T, het kunnen toepassen van kennis en technieken in de praktijk, analytische en diagnostische vaardigheden, kwantitatieve vaardigheden, probleemoplossing, sociale vaardigheden 
(contactuele vaardigheden en teamwork), zelfstandigheid, omgaan met belangentegenstellingen en kritische reflectie.

FdR: $\quad$ Vergeleken met elders afgestudeerde juristen vinden afgestudeerden van de FdR vaker dat hun opleiding tekortschiet als het gaat om de hoeveelheid aandacht die ICT in hun opleiding heeft gekregen. Zij zijn echter vaker tevreden als het gaat om de bestede aandacht voor vakspecifieke M\&T, de praktische toepassing van kennis, het oplossen van problemen, werken in teamverband en initiatief, creativiteit.

Tabel 4.4

Gewenste aandacht in opleiding voor competenties (\% meer aandacht nodig), UM-landelijk (meetjaar 1998)

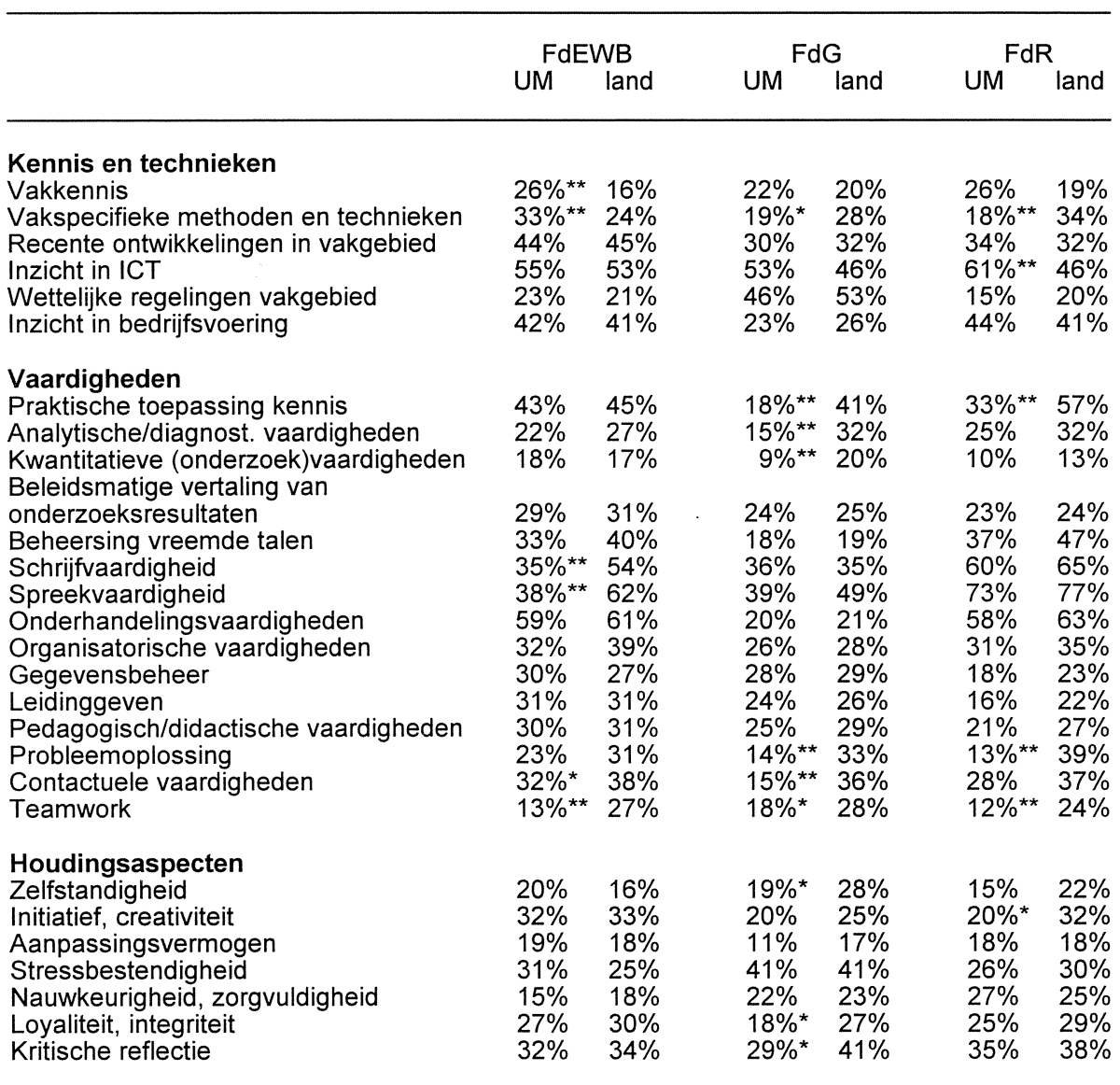

* Verschil UM-landelijk significant op 5\%-niveau.

** Verschil UM-landelijk significant op $1 \%$-niveau.

Wellicht zijn bovengenoemde verschillen mede toe te schrijven aan het systeem van probleemgestuurd onderwijs in groepen (PGO) dat aan de UM wordt toegepast. Echter, in hoeverre PGO debet is aan bovengenoemde verschillen valt zonder nader onderzoek niet aan te geven. 


\section{Rapportcijfers voor aspecten van de opleiding}

Zoals eerder reeds is aangegeven, is aan de afgestudeerden gevraagd een 'rapportcijfer' te geven aan een zevental aspecten van de opleiding. Welnu, bij elk van de zeven in tabel 4.5 genoemde opleidingsaspecten scoort steeds een of meerdere faculteiten van de UM boven het desbetreffende landelijke gemiddelde. Hierna wordt kort hierop ingegaan.

Tabel 4.5

Gemiddeld 'rapportcijfer' voor aspecten van de opleiding, UM-landelijk (meetjaar 1998)

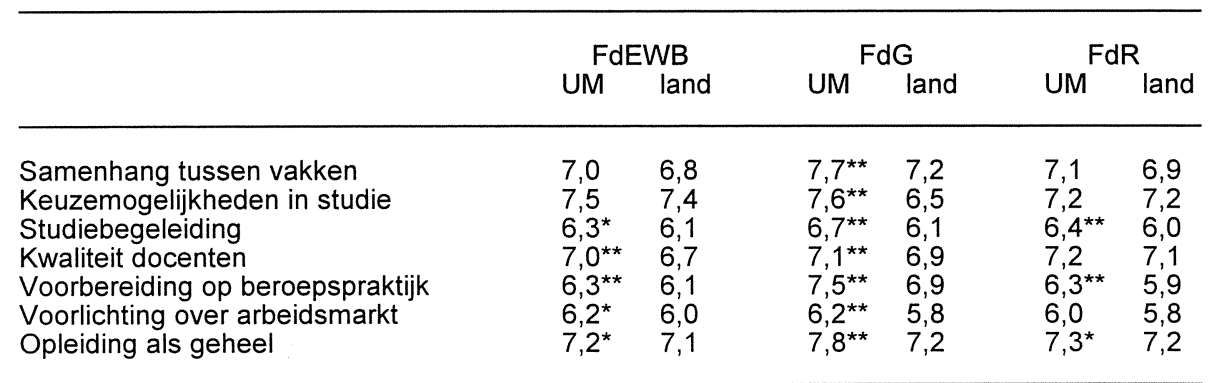

* Verschil UM-landelijk significant op 5\%-niveau.

** Verschil UM-landelijk significant op $1 \%$-niveau.

FdEWB: Aan de UM afgestudeerde economen zijn beter dan hun elders afgestudeerde vakgenoten te spreken over de begeleiding die zij tijdens hun opleiding hebben gekregen, de kwaliteit van het docentenkorps, de voorbereiding op de beroepspraktijk, de voorlichting over de arbeidsmarktsituatie en de opleiding als geheel.

FdG: $\quad$ Op elk van de zeven opleidingsaspecten scoort de FdG in de ogen van de afgestudeerden boven het gemiddelde voor geneeskundefaculteiten.

FdR: $\quad$ Vergeleken met elders afgestudeerde juristen zijn afgestudeerden van de FdR meer tevreden over de begeleiding die zij tijdens hun opleiding hebben gekregen, de voorbereiding op de beroepspraktijk en de opleiding als geheel.

\section{Moeilijkheidsgraad van de opleiding}

Bij elk van de drie faculteiten kan worden geconstateerd dat de afgestudeerden niet significant verschillen van hun elders afgestudeerde vakgenoten wat hun mening over de moeilijkheidsgraad van de gevolgde opleiding betreft (tabel 4.6).

\section{Specialisatiegraad van de opleiding}

In Maastricht afgestudeerde basisartsen vinden vaker dan elders afgestudeerde vakgenoten dat hun opleiding precies voldoende is gespecialiseerd (tabel 4.7). Afgestudeerden van de FdEWB en FdR verschillen niet significant van elders afgestudeerde vakgenoten wat hun mening over de mate van specialisatie van de gevolgde opleiding betreft. 
Tabel 4.6

Oordeel over de moeilijkheidsgraad van de opleiding, UM-landelijk (meetjaar 1998)

\begin{tabular}{|c|c|c|c|c|c|c|}
\hline & \multicolumn{2}{|c|}{ FdEWB } & \multicolumn{2}{|c|}{ FdG } & UM ${ }^{F C}$ & land \\
\hline $\begin{array}{l}\text { Moeilijkheidsgraad is: } \\
\text { * Niet hoog genoeg } \\
{ }^{*} \text { Precies goed } \\
\text { * Te hoog }\end{array}$ & $\begin{array}{r}23 \% \\
77 \% \\
1 \%\end{array}$ & $\begin{array}{r}23 \% \\
75 \% \\
2 \%\end{array}$ & $\begin{array}{r}30 \% \\
70 \% \\
0 \%\end{array}$ & $\begin{array}{r}28 \% \\
70 \% \\
1 \%\end{array}$ & $\begin{array}{r}35 \% \\
65 \% \\
0 \%\end{array}$ & $\begin{array}{r}29 \% \\
70 \% \\
1 \%\end{array}$ \\
\hline
\end{tabular}

Tabel 4.7

Oordeel over de specialisatiegraad van de opleiding, UM-landelijk (meetjaar 1998)

\begin{tabular}{lrrrrrr}
\hline & \multicolumn{2}{c}{ FdEWB } & \multicolumn{2}{c}{ FdG } & \multicolumn{2}{c}{ FdR } \\
& UM & land & UM & land & UM & land \\
\hline $\begin{array}{l}\text { De opleiding is: } \\
\text { * Onvoldoende gespecialiseerd }\end{array}$ & $17 \%$ & $19 \%$ & $9 \%$ & $17 \%$ & $23 \%$ & $27 \%$ \\
* Precies voldoende gespeciali- & $76 \%$ & $75 \%$ & $91 \%$ & $76 \%$ & $73 \%$ & $69 \%$ \\
$\begin{array}{l}\text { seerd } \\
\text { Te specialistisch }\end{array}$ & $7 \%$ & $6 \%$ & $0 \%$ & $7 \%$ & $4 \%$ & $4 \%$ \\
\hline
\end{tabular}

Verschil geneeskunde UM - geneeskunde landelijk significant op 1\%-niveau.

Tabel 4.8

Studiekeuze achteraf bezien, UM-landelijk (meetjaar 1998)

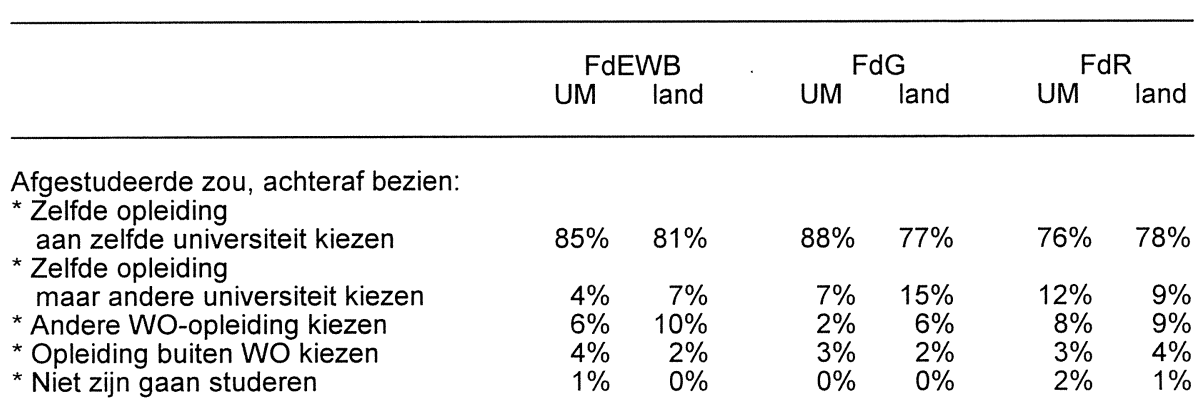

Verschil geneeskunde UM - geneeskunde landelijk significant op 5\%-niveau.

Studiekeuze achteraf bezien

Zoals eerder is gezegd, kan het antwoord op de vraag of de afgestudeerden achteraf bezien opnieuw dezelfde opleiding aan dezelfde universiteit zouden zijn gaan volgen, worden beschouwd als een indicatie van hun algemene tevredenheid over de destijds gemaakte studiekeuze. Tabel 4.8 toont dat de aan de UM afgestudeerde basisartsen vaker opnieuw voor dezelfde opleiding aan dezelfde universiteit zouden kiezen dan hun elders afgestudeerde vakgenoten. Laatstgenoemden zijn weliswaar nagenoeg even vaak tevreden met de destijds gekozen opleiding als Maastrichtse basisartsen, maar niet met hun universiteit: zij zouden achteraf bezien vaker geneeskunde aan een andere universiteit zijn gaan studeren dan Maastrichtse basisartsen. Afgestudeerden van de FdEWB en FdR verschillen 
niet significant van elders afgestudeerde vakgenoten wat hun tevredenheid over de destijds gemaakte studiekeuze betreft.

Resumerend, is uit de vergelijking van afgestudeerden van de UM met elders afgestudeerden naar voren gekomen dat afgestudeerden van de UM niet significant afwijken van afgestudeerden van andere universiteiten wat betreft de kans op werk (werkloosheid), zekerheid van het werk (aandeel vaste aanstellingen) en de aansluiting van het werk naar opleidingsniveau en -richting. Er zijn wel significante, faculteitspecifieke verschillen tussen afgestudeerden van de UM en elders afgestudeerden als het gaat om het oordeel over sommige aspecten van de opleiding. 


\section{Bijlage: Technische toelichting}

Aanbieden op de arbeidsmarkt:

Het percentage afgestudeerden dat op het moment van enquêteren tot de beroepsbevolking behoort. Tot de beroepsbevolking behoren conform de definitie van het Centraal Bureau voor de Statistiek (CBS) afgestudeerden die tenminste 12 uur per week betaald werken, afgestudeerden die werk hebben aanvaard waardoor zij tenminste 12 uur per week betaald gaan werken en afgestudeerden die tenminste 12 uur per week willen werken, daarvoor beschikbaar zijn en daartoe tevens activiteiten ontplooien. Tevens is als voorwaarde gesteld dat de voornaamste bezigheid van de afgestudeerden niet 'student' is. Afgestudeerden die zich aanbieden op de arbeidsmarkt oftewel tot de beroepsbevolking behoren zijn óf werkend (zie ook 'werkende') óf werkloos (zie 'werkloosheidspercentage').

Aansluiting opleiding-functie:

Het subjectieve oordeel van de betaald-werkende afgestudeerde over de aansluiting tussen de gevolgde WO-opleiding en de huidige functie.

\section{Beloning:}

Het betreft het bruto loon inclusief toeslagen voor onregelmatige dienst, fooi, provisie e.d., maar exclusief loon uit overwerk, vakantiegeld, dertiende maand, uitkering, (studie)beurs e.d.

Het bruto maandloon betreft inkomsten uit zowel de hoofdfunctie als eventuele nevenfuncties. Voor het berekenen van het bruto uurloon zijn eventuele uitkomsten uit nevenfuncties niet meegerekend.

Deelname aan vervolgonderwijs:

Het percentage afgestudeerden dat ná het verlaten van de WO-opleiding op enigerlei moment een vervolgopleiding heeft gevolgd.

Deelname aan cursus/bedrijfsopleiding:

Het percentage afgestudeerden dat op het moment van de enquête een cursus of bedrijfsopleiding volgt.

Eigen of verwante opleidingsrichting vereist:

Het percentage van de werkende afgestudeerden dat aangeeft dat door de werkgever dezelfde of een verwante opleidingsrichting als de gevolgde opleiding werd vereist voor de huidige functie (zie ook 'vereiste opleidingsrichting').

Full-time baan:

Het percentage van de werkende (zie 'aanbieden op de arbeidsmarkt') afgestudeerden dat meer dan 32 uur per week betaald werk verricht. 
Part-time baan:

Het percentage van de werkende (zie 'aanbieden op de arbeidsmarkt') afgestudeerden dat minder dan 33 uur per week betaald werk verricht.

Werkende (afgestudeerde):

Een afgestudeerde die tot de werkzame beroepsbevolking behoort. Tot de werkzame beroepsbevolking behoren afgestudeerden die tenminste 12 uur per week betaald werken en afgestudeerden die werk hebben aanvaard waarvoor zij tenminste 12 uur per week betaald gaan werken. Tevens is als voorwaarde gesteld dat de voornaamste bezigheid van de afgestudeerde niet 'student' is (zie ook 'aanbieden op de arbeidsmarkt').

Werkloosheidspercentage:

Het percentage van het aantal afgestudeerden dat zich aanbiedt op de arbeidsmarkt (zie 'aanbieden op de arbeidsmarkt') en tot de werkloze beroepsbevolking behoort oftewel werkloos is. Tot de werkloze beroepsbevolking behoren conform de definitie die bijvoorbeeld ook door het Centraal Bureau voor de Statistiek wordt gehanteerd - afgestudeerden zonder betaald werk (of met betaald werk van minder dan 12 uur per week) die minstens 12 uur per week betaald willen werken, daarvoor direct beschikbaar zijn en bovendien actief zoeken naar betaald werk (ongeacht of men bij het arbeidsbureau staat ingeschreven). Tevens is als voorwaarde gesteld dat de voornaamste bezigheid van de afgestudeerden niet 'student' is (zie ook 'aanbieden op de arbeidsmarkt').

Werkzaam in de regio:

Het percentage werkende afgestudeerden dat in dezelfde regio werkt als de regio waarin de WO-opleiding is gevolgd. De indeling in regio's is conform de zogenaamde RBA-indeling (RBA: Regionaal Bestuur voor de Arbeidsvoorziening).

Werkzekerheid:

Het percentage van de werkende afgestudeerden met een vaste aanstelling of een tijdelijke aanstelling met uitzicht op een vaste baan.

WO-niveau vereist:

Het percentage van de werkende afgestudeerden dat aangeeft dat door de werkgever een opleiding op universitair niveau werd vereist voor de huidige functie.

Zou zelfde opleiding aan zelfde universiteit kiezen:

Het percentage afgestudeerden dat, achteraf bezien, opnieuw voor dezelfde opleiding aan dezelfde universiteit zou kiezen. 